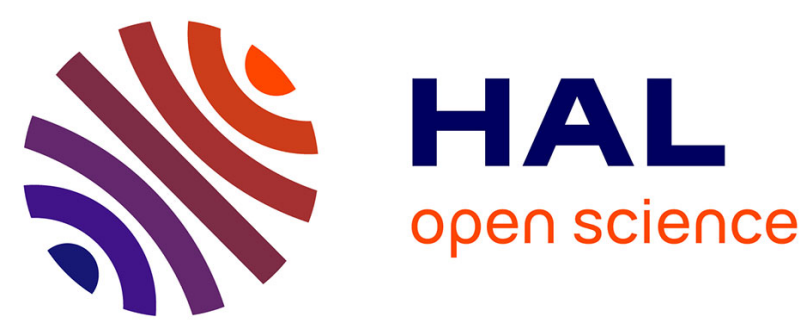

\title{
Denudation intensity and control in the Chinese Tian Shan: new constraints from mass balance on catchment-alluvial fan systems
}

Laure Guerit, Laurie Barrier, Marc Jolivet, Bihong Fu, François Métivier

\section{- To cite this version:}

Laure Guerit, Laurie Barrier, Marc Jolivet, Bihong Fu, François Métivier. Denudation intensity and control in the Chinese Tian Shan: new constraints from mass balance on catchment-alluvial fan systems. Earth Surface Processes and Landforms, 2016, 41 (8), pp.1088-1106. 10.1002/esp.3890 . insu-01249993

\section{HAL Id: insu-01249993 https://hal-insu.archives-ouvertes.fr/insu-01249993}

Submitted on 6 Nov 2020

HAL is a multi-disciplinary open access archive for the deposit and dissemination of scientific research documents, whether they are published or not. The documents may come from teaching and research institutions in France or abroad, or from public or private research centers.
L'archive ouverte pluridisciplinaire HAL, est destinée au dépôt et à la diffusion de documents scientifiques de niveau recherche, publiés ou non, émanant des établissements d'enseignement et de recherche français ou étrangers, des laboratoires publics ou privés. 


\title{
Denudation intensity and control in the Chinese Tian Shan: new constraints from mass balance on catchment-alluvial fan systems
}

\author{
Laure Guerit,, ${ }^{1,2 *}$ Laurie Barrier, ${ }^{1}$ Marc Jolivet, ${ }^{3}$ Bihong Fu ${ }^{4}$ and François Métivier ${ }^{1}$ \\ ${ }^{1}$ Institut de Physique du Globe de Paris, Sorbonne Paris Cité, Université Paris Diderot, UMR 7154 CNRS, F-75005 Paris, France \\ 2 Department of Earth Science, University of Geneva, 1205 Geneva, Switzerland \\ 3 Université Rennes 1, Laboratoire Géosciences Rennes, UMR6118 CNRS/INSU, Campus de Beaulieu, 35042 Rennes, France \\ ${ }^{4}$ State Key Laboratory of Lithospheric Evolution, Institute of Geology and Geophysics, Chinese Academy of Sciences, Beijing, \\ China
}

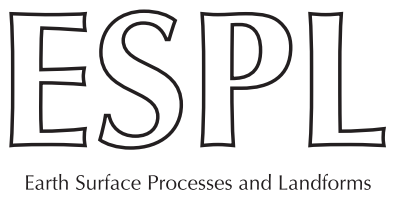

ABSTRACT: Tectonics and climate are usually seen as the main controlling factors of denudation rates, which seem to rise with the tectonic activity and to decrease when the climate becomes drier. However, the low denudation rates observed in semi-arid to arid contexts are generally measured on orogenic plateaus where the respective influence of the flat relief and the dry climate cannot really be unravelled. The Chinese Tian Shan was chosen as a case study. In the northern piedmont of this mountain range, a series of well-preserved Quaternary alluvial fans offer the opportunity to perform a mass balance study at the scale of several catchment areas and several hundreds of thousands of years. Based on a geometrical reconstruction of these fans, the volumes of sediments exported out of 10 drainage basins during the Middle-Late Pleistocene (from 300 to 12 kyr) and the Holocene (from $\sim 12 \mathrm{kyr}$ to present) have been estimated. From these volumes, an average denudation rate of $\sim 135 \mathrm{~m} / \mathrm{Myr}$ was determined in the Tian Shan Range for the last 300 kyr. In agreement with other mass balances performed in the same area, the typical denudation intensity of the northern Tian Shan is thus of a few hundred meters per million years at most, regardless of the space and time scales considered. From a comparison with denudation rates in other mountain ranges throughout the world, we suggest that a dry climate can dramatically limit the denudation intensity even in active orogenic systems with a high topographic gradient like the Tian Shan. As a result, the time required to reach equilibrium between denudation and rock uplift in these systems could be extremely long (i.e. of more than several million years). Copyright (C) 2016 John Wiley \& Sons, Ltd.

KEYWORDS: denudation; mass balance; alluvial fan; Tian Shan; climate

\section{Introduction}

Denudation is a key process for mountain range evolution and the quantification of denudation rates is crucial to better constrain topography dynamics and mass transfer in orogenic systems (e.g. Molnar and England, 1990; Métivier et al., 1999; Kirchner et al., 2001; Farías et al., 2008; Simoes et al., 2010), as well as interactions between erosion, tectonics and climate (e.g. Raymo and Ruddiman, 1992; Avouac and Burov, 1996; Whipple, 2009; laffaldano et al., 2011).

These two forcings are usually seen as the main controlling factors of the denudation intensity (e.g. Riebe et al., 2001; Zhang et al., 2001; Vance et al., 2003; Binnie et al., 2010), but their respective influences depend strongly on the studied areas. Tectonics can be the dominant control (e.g. Riebe et al., 2001; Burbank et al., 2003; von Blanckenburg, 2005; Herman et al., 2010) or climate (e.g. Reiners et al., 2003; Grujic et al., 2006; Clift et al., 2008), and in some contexts it is not possible to determine the prevalence of one or the other (e.g. Dadson et al., 2003; Clift, 2006). Nonetheless, two trends seem to emerge from the existing data compilations
(Wittmann et al., 2007; Matmon et al., 2009; Covault et al., 2013): denudation rate rises with the tectonic activity whereas it decreases when the climate becomes more arid.

However, studies in semi-arid to arid contexts mostly focused on orogenic plateaus, such as the Tibet or Andes interiors (e.g. Lal et al., 2004; Chappell et al., 2006; Kober et al., 2007; Kong et al., 2007; Hippe et al., 2012). Yet low denudation rates could also be linked to flat relief (e.g. Summerfield and Hulton, 1994; Montgomery and Brandon, 2002; Carretier et al., 2013), hence the climatic control cannot really be asserted on plateaus. Very few studies have quantified denudation in orogenic systems where precipitations are less than 500 $\mathrm{mm} / \mathrm{yr}$ but with strong topographic gradient (Ali et al., 2003; Pan et al., 2010) and there is still a clear need to document denudation in such ranges.

Denudation rates are often determined by thermochronology (e.g. Bullen et al., 2003; Dadson et al., 2003; Grujic et al., 2006; Jolivet et al., 2007, 2013a), cosmogenic isotopes (e.g. Brown et al., 1995; Granger et al., 1996; von Blanckenburg, 2005; Charreau et al., 2011), or mass balances (Hinderer, 2012, and references therein). The mass balance 
studies usually consist of sediment budgets from sedimentary basins or of sediment load measurements in present-day rivers (e.g. Métivier and Gaudemer, 1997; Gabet et al., 2008; Barnes and Heins, 2009; Liu et al., 2011; Calvès et al., 2013). These approaches face several issues. On one hand, sediment budgets from sedimentary basins provide long-term values averaged over large areas. On the other hand, sediment load measurements give short-term values specific to the sampling location. Unless there is evidences that measurements can be extended over the whole drainage basin, huge field sampling efforts are then necessary to have a general view of the sediment budget within a complete river system.

Occasionally, mass balance is also performed on catchment-fan systems (Kiefer et al., 1997; Oguchi, 1997; Allen and Hovius, 1998; Jayko, 2005; Hornung et al., 2010; Jolivet et al., 2014). They cover intermediate scales that are complementary to those of other sediment budget approaches, both in space and time (Hinderer, 2012). In fact, catchment-fan mass balances offer a better spatial resolution than sediment budgets from sedimentary basins. They are also more integrative in space and time, and they are easier to implement than sediment load measurements. For these reasons, catchment-fan sediment budgets are of great interest in discussing the evolution of denudation in space and/or time in a given area. However, the characteristic denudation intensity in a region over different time scales can only be determined if all these methods are used together (e.g. Kirchner et al., 2001; Dadson et al., 2003; Matmon et al., 2003).

The Chinese Tian Shan Range is a high mountain belt located in Central Asia (Figure 1a) in a semi-arid to arid climate and it was chosen as a case study. On its northern side, which rises from $600 \mathrm{~m}$ a.s.l. up to more than $5000 \mathrm{~m}$ a.s.l., denudation rates have already been estimated by several methods, at different space and time scales (Métivier and Gaudemer, 1997; Charreau et al., 2011; Liu et al., 2011; Puchol, 2013; Jolivet et al., 2014). In this area, the piedmont is formed by a series of exceptionally well-preserved Quaternary alluvial fans (Avouac et al., 1993; Poisson, 2002; Lu et al., 2010). They are located at the transition between the catchment areas and the sedimentary foreland basin, which is a strategic position to record the denudation history of the range. Moreover, rivers have deeply incised the old fans, whose basal surfaces are presently visible in outcrop. These fans offer the opportunity to improve the existing denudation data of the mountain range by a mass balance at intermediate space and time scales (several drainage basins and several hundred of thousands years).

In this paper, the methodology and results of this mass balance are presented, before discussing the denudation intensity and controls in the northern Tian Shan. From a comparison with denudation rates in other ranges, we suggest that dry climatic conditions strongly limit the denudation magnitude even in ranges where the topographic gradient is high, notwithstanding the tectonics activity.

\section{Geological Setting}

The Tian Shan is an east-west, $2500 \mathrm{~km}$ long, and up to 7400 $\mathrm{m}$ high, mountain belt that extends over western China, Kazakhstan and Kyrgyzstan (Figure 1a). After a complex Palaeozoic and Mesozoic orogenic history (e.g. Windley et al., 1990; Allen et al., 1992; Hendrix et al., 1992; Gao et al., 1998; Zhou et al., 2001; Jolivet et al., 2010, 2013b), the Tian Shan was reactivated during the Cenozoic in response to the India-Asia collision (e.g. Tapponnier and Molnar, 1977; Avouac et al., 1993; Hendrix et al., 1994; Dumitru et al., 2001; Charreau et al., 2009a; Jolivet et al., 2010). Today, the range is still active, with a mean GPS shortening rate of up to $\sim 2 \mathrm{~cm} / \mathrm{yr}$ (Abdrakhmatov et al., 1996; Reigber et al., 2001; Zubovich et al., 2010). In its Chinese part, the northern side of the range is separated from the Junggar foreland basin by three series of east-west oriented fault propagation folds (Figure 1b). A major thrust zone generally separates this faulted and folded piedmont from the exhumed basement that forms the high range (Avouac et al., 1993; Burchfiel et al., 1999; Guan et al., 2009; Lu et al., 2010; Chen et al., 2014). In the piedmont, the slope rarely exceeds $25^{\circ}$, but it rises up to $40^{\circ}$ in the range (Figure 1c).

Over the whole Cenozoic, the regional climate oscillated between semi-humid and semi-arid periods (Molnar et al., 1994; Rhodes et al., 1996; Yi et al., 2004; Poisson and Avouac, 2004; Gallaud, 2008; Sun and Zhang, 2008; Xu et al., 2010), and for the last $550 \mathrm{kyr}$ several phases of glacial advances have been recorded in relation to the global glacial-interglacial cycles (Zhao et al., 2009). The last major deglaciation occurred about $12 \mathrm{kyr}$ ago and was followed by a period of more abundant precipitations (Rhodes et al., 1996; Poisson and Avouac, 2004). However, since $6 \mathrm{kyr}$, the region has become increasingly arid. Nowadays, the regional climate is continental and semi-arid, influenced by the Westerlies and the Asian monsoon. Precipitation is typically less than 250 $\mathrm{mm} / \mathrm{yr}$ in the northern piedmont (from $250 \mathrm{~mm} / \mathrm{yr}$ around the city of Urumqi to less than $100 \mathrm{~m} / \mathrm{yr}$ in the West), and rises up to $300-400 \mathrm{~mm} / \mathrm{yr}$ in the range (Métivier and Gaudemer, 1997; Poisson, 2002; Sobel et al., 2003).

In China, a dozen large rivers drain the northern side of the range (Figure $1 \mathrm{~b}$ ). They originate from glaciers in the hinterland mountains at an elevation of $\sim 4000 \mathrm{~m}$ a.s.l. and flow northwards to the Junggar Basin, located about $3300 \mathrm{~m}$ below. In the piedmont, these rivers have built and incised several alluvial fans (Avouac et al., 1993; Poisson, 2002; Lu et al., 2010) (Figure 2). At least three sequences of fan growth, followed by abandonment and incision (Figure 2), occurred over the last $550 \mathrm{kyr}$ (Zhou et al., 2002; Lu et al., 2010). The last abandonment-fan growth sequence initiated about 12 kyr ago during the last deglaciation (Avouac et al., 1993; Poisson, 2002; Poisson and Avouac, 2004; Lu et al., 2010; Gong et al., 2014). According to optically stimulated luminescence, electron spin resonance, ${ }^{10} \mathrm{Be}$ and ${ }^{14} \mathrm{C}$ dating, the alluvial fans abandoned at that time (called F3 in Lu et al. (2010) and $F_{p}$ in this study, see Table I for term definitions) are Middle-Late Pleistocene in age, as they were active between $\sim 300 \mathrm{kyr}$ and $\sim 12 \mathrm{kyr}$ for a total period of $277 \pm 30 \mathrm{kyr}$ (Molnar et al., 1994; Poisson, 2002; Poisson and Avouac, 2004; Lu et al., 2010; Yang et al., 2013; Gong et al., 2014). These fans are now deeply incised by up to $300 \mathrm{~m}$ deep canyons carved by the rivers (the $\mathrm{KMZ}$ coordinates of the river paths are given in Supplementary Data SA - supporting information) during the Holocene. As a consequence, the $F_{p}$ fan basal surface is sometimes visible along the cliffs surrounding active river channels (Figures $2 \mathrm{~b}$ and 3 ). Contemporaneous with this incision, a new generation of fans formed downstream in the Junggar Basin. These fans (called F4 in (Lu et al., 2010) and $F_{h}$ in this study) are Holocene in age and have been active for a period of $11.3 \pm 2.3$ kyr (Poisson and Avouac, 2004; Lu et al., 2010). Remains of older fans exist in the region (F1 and F2 in Lu et al., 2010), but this study focuses on the two last generations only.

All the catchment-fan systems of the northern side of the Chinese Tian Shan exhibit similar and probably coeval fan systems and canyons, which developed during the last glacial and interglacial periods (Molnar et al., 1994; Poisson, 2002; Poisson and Avouac, 2004; Lu et al., 2010; Gong et al., 


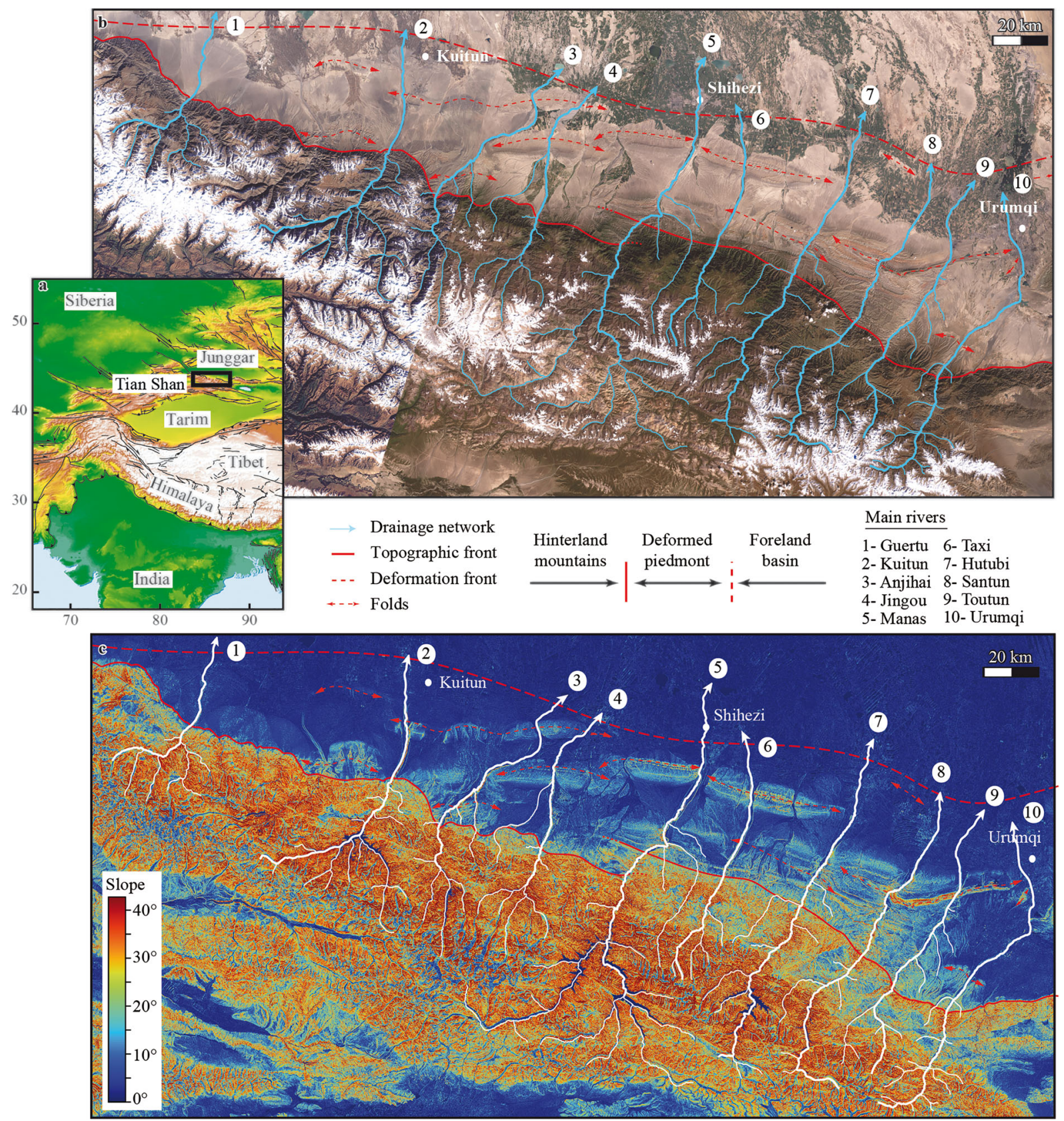

Figure 1. (a) Location of the Tian Shan; (b) satellite imagery (Landsat picture); (c) slope map of the northern side of the Chinese Tian Shan. The 10 river systems considered are named after Zhou et al. (1999). This figure is available in colour online at www.interscience.wiley.com/journal/espl.

2014). Moreover, the locations of the river incisions generally do not correlate with active tectonic structures. For example, along the $\sim 40 \mathrm{~km}$ long Kuitun River canyon, tectonic uplift affects a zone of $\simeq 5 \mathrm{~km}$ in length, which is known as the Dushanzi anticline. It has been shown by Poisson (2002) and Poisson and Avouac (2004) that this anticline cannot account for more than $10 \%$ of the local incision. Consequently, the fan aggradation-incision cycle is climate-driven and linked to changes in water and/or sediment discharges (Poisson, 2002; Poisson and Avouac, 2004).

Finally, the fans $F_{p}$ and $F_{h}$ are made up by conglomerates with grains from silts to metric boulders, with a porosity of $20 \pm 10 \%$ (Clarke, 1979; Guerit, 2014). The Urumqi River is the only river where the sediment transport is quantitatively documented. Measurements in the upper part of its catchment show that $17.3 \pm 0.3 \%$ of the material is transported as bedload, $35.2 \pm 6.7 \%$ as suspended load and $47.5 \pm 6.5 \%$ as dissolved load (Liu et al., 2011). Based on the morphologi- cal similarities between the catchment-fan systems in northern Chinese Tian Shan, we assumed that these ratios are identical along the whole river path and through time, for all the studied systems.

\section{Data and Methodology}

The objective of this study was, first, to determine the volume of sediments that have been exported out of the drainage basins and deposited in the fans $F_{p}$ and $F_{h}$, and secondly, to convert these volumes into denudation rates for the Middle-Late Pleistocene (from $\sim 300 \mathrm{kyr}$ to $\sim 12 \mathrm{kyr}$ ) and the Holocene (from $\sim 12 \mathrm{kyr}$ to present).

In order to reconstruct the sediment volumes, two morpho-sedimentary maps of the northern side of the Chinese Tian Shan were drawn to locate accurately the Middle-Late Pleistocene and Holocene alluvial fans and their catchment areas based on satellite images (Landsat and Digital Globe 

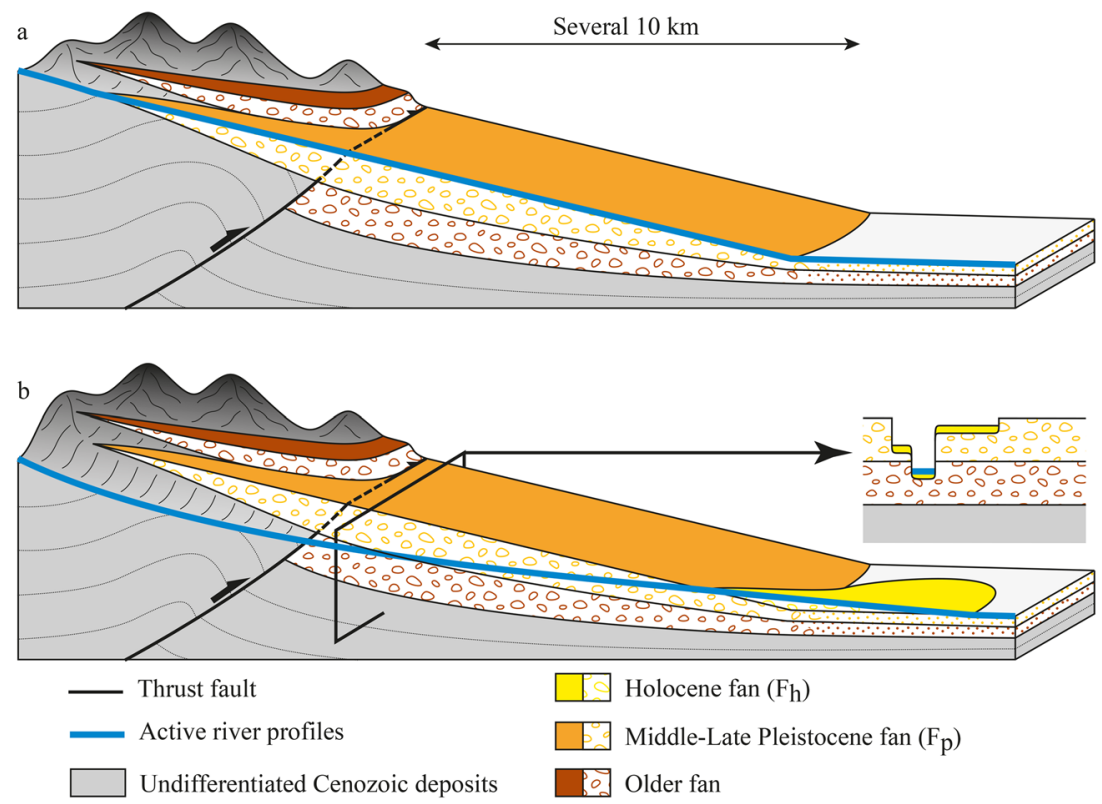

Figure 2. Morphology in cross-section of the northern Chinese Tian Shan piedmont (a) at the end of the Pleistocene and (b) nowadays, after the incision of the Middle-Late Pleistocene fans. The basal surface of these fans is now exposed along the cliffs surrounding active river channels. This figure is available in colour online at www.interscience.wiley.com/journal/espl.
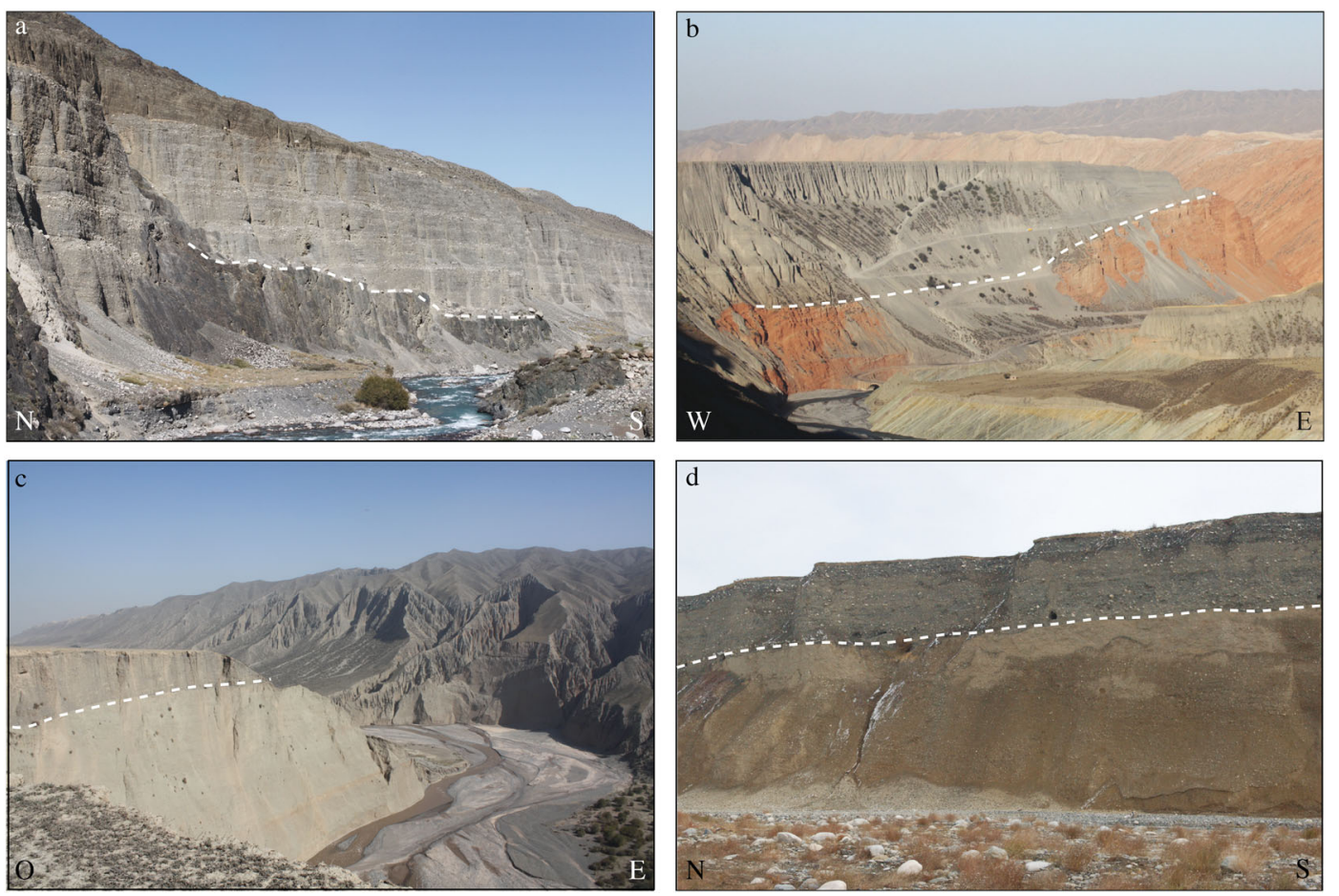

Figure 3. Outcrops of Middle-Late Pleistocene fan basal surfaces along the (a) Guertu, (b) Anjihai, (c) Hutubi and (d) Urumqi rivers. These basal surfaces (white dash lines) are emphasized by a contrast in (a, b, c, d) colour, and (a, b) lithology between the dark-grey deposits of the Pleistocene fans and the older terrains. In the presented examples, these terrains correspond to (a) Paleozoic bedrock, (b) Tertiary orange silts, sandstones and conglomerates, and (c, d) Tertiary and Quaternary light-grey conglomerates. The cliffs are a few dozen (d) up to a few hundred (b) metres high. This figure is available in colour online at www.interscience.wiley.com/journal/espl.

pictures) and a digital elevation model (ASTER GDEM2). The DEM were then used to model the fan top surfaces, and field data to reconstruct the fan basal surfaces. From these modelled surfaces, isopach maps were obtained and the volumes of sediments trapped in the fans were calculated. These volumes were converted into Middle-Late Pleistocene and Holocene denudation rates for each drainage basin, which were averaged to estimate the denudation rate of the whole northern side of the Tian Shan.

\section{Morpho-sedimentary maps of the catchment-fan systems}

Several morpho-sedimentary maps of the region are available, but the different data used and the variety of purposes have led to inconsistencies between these published documents (Avouac et al., 1993; Poisson, 2002; Graveleau, 2008; Charreau et al., 2009b; Lu et al., 2010). In particular, the extension of fans and drainage basins differ from one map 
Table I. Terms and definitions used in this study

\begin{tabular}{ll}
\hline Term & \\
\hline$F_{p}$ & Middle-Late Pleistocene fans \\
$F_{h}$ & Holocene fan. \\
$A_{F_{p}}$ & Areas of the fans $F_{p}$ \\
$A_{F_{h}}$ & Areas of the fans $F_{h}$ \\
$A_{d p}$ & Areas of the Middle-Late Pleistocene drainage basins \\
$A_{d h}$ & Areas of the Holocene drainage basins \\
$A_{d, h-p}$ & Areas of the Holocene extension of the drainage basins \\
$V_{F_{p}}$ & Volumes of the fans $\mathrm{F}_{p}$ \\
$V_{F_{h}}$ & Volumes of the fans $\mathrm{F}_{h}$ \\
$V_{c}$ & Volumes of the Holocene canyons dug into the piedmont \\
$V_{\lambda F_{p}}$ & Volumes of sediments in the fans $\mathrm{F}_{p}$ \\
$V_{\lambda F_{h}}$ & Volumes of sediments in the fans $\mathrm{F}_{h}$ \\
$V_{\lambda c}$ & Volumes of sediments removed from the Holocene canyons \\
$V_{\lambda, F_{h}-c}$ & Difference between the volumes of sediments trapped in the fans $\mathrm{F}_{h}$ and removed from the Holocene canyons \\
$\lambda$ & Sediment porosity (20 $\pm 10 \%)$ \\
$\alpha$ & Fraction of the total river load trapped in fans $(17.3 \pm 0.3 \%)$ \\
$\mathrm{P}_{p}$ & Period of $\mathrm{F}_{p}$ fan construction $(277 \pm 30$ kyr $)$ \\
$\mathrm{P}_{h}$ & Period of $\mathrm{F}_{h}$ fan construction $(11.3 \pm 2.3 \mathrm{kyr})$ \\
$\epsilon_{p}$ & Middle- Late Pleistocene denudation rates \\
$\epsilon_{h}$ & Holocene total denudation rates \\
$\epsilon_{c}$ & Holocene denudation rates in the piedmont \\
$\epsilon_{r}$ & Holocene denudation rates in the range \\
\hline
\end{tabular}

to another, and the distinction between the Pleistocene and Holocene features (fans, canyons) is not always considered. In addition, these documents mostly focus on the central part of the piedmont only. Therefore, to perform a study on the whole piedmont and to accurately locate the outlines of the fans $F_{p}$ and $F_{h}$ and their respective catchment areas, two new morpho-sedimentary maps based on satellite images, digital elevation model and field observations were drawn. One concerns the Late Pleistocene landscape (Figure 4) and the other one the present-day landscape (Figure 5). The map construction and uncertainties are detailed in Appendix A. These maps enabled the extraction of the drainage basins and fan outlines for the two periods (KMZ coordinates given in Supplementary Data S2, S3, S4 and S5) and their areas (Tables II and III). Note that in this study only the 10 catchment-fan systems for which the position of the basal surface of the fans $F_{p}$ could be identified in the field were considered.

\section{Volumes of sediments}

\section{Fan outlines}

Given their growth dynamics, the outlines of the fans $F_{p}$ and $\mathrm{F}_{h}$ can be used to map the extent of both their top and basal surfaces. Outline elevations were extracted from the ASTER DEM ( $10 \mathrm{~m}$ vertical resolution) with a point every meter, and interpolated when required (e.g. where fan outlines have been eroded or covered by other deposits). Finally, a sliding window over $10 \mathrm{~m}$ was applied to the dataset in order to filter the DEM noise.

Fan top surfaces

For the two fan generations, the top surface elevations were extracted from the ASTER DEM with a grid resolution of 250 $\mathrm{m}$. Here again, data were interpolated to recover the original fan surface over the areas of the fan surface 'damaged' by posterior erosion and deposition, or by human land uses. Two different interpolation schemes (linear or cubic) were used in order to quantify the error associated with the interpolation method. The final fan top surface was then obtained on a $250 \times 250 \mathrm{~m}$ model grid (Figure 6a, b) .
Fan basal surfaces

The basal surfaces of the Middle-Late Pleistocene fans were reconstructed from field surveys along the river canyons. As explained above, the rivers of the northern Chinese Tian Shan have incised the fans $F_{p}$ during the Holocene. In the cliffs surrounding the streams, the $F_{p}$ basal surfaces are often identifiable, due to contrasts in sediment colour, lithology or dip between the fan deposits and older series (Figure 3). However, the further from the relief, the more difficult this identification as the contrasts become less and less marked (see Appendix B.1 for details on outcrop identification and data acquisition). Consequently, the $\mathrm{F}_{p}$ basal surface outcrops were mostly identified close to the fan apexes or to the anticlines in the piedmont (Figure 7a, b; Data S6).

The $\mathrm{F}_{p}$ basal surfaces were modelled from this dataset on the basis of two hypothesis. First, in agreement with field observations (Figure $3 \mathrm{~b}$ ), we considered that the basal surfaces are parabolic in transverse cross-section (Figure 7c). Then, we assumed that the basal surfaces are regular between two points and that there is no major tectonic or topographic structure hidden underneath the fans (Figure $7 d$ ). Finally, the interpolation methods presented for the top surface reconstruction were used to model the fan basal surfaces over $250 \times 250$ m model grids (Figure 6c).

As the Holocene fans have not been incised, the position of their basal surface could not be determined from direct observation. Therefore, we considered that fans $F_{h}$ were built over a topography composed of two gently sloping surfaces: the surface of the fans $F_{p}$ (slope $\sim 1-2.5 \%$ ) followed to the north by the downstream alluvial plain (slope $\sim 0.2-0.4 \%$ ), in agreement with (Jolivet et al., 2014). Here again, the methods of interpolation described above were implemented to model the $\mathrm{F}_{h}$ basal surfaces over $250 \times 250 \mathrm{~m}$ grids (Figure $6 \mathrm{~d}$ ).

Fan and sediment volumes

Fan thickness maps were built as the difference in elevation between the reconstructed top and basal surfaces of the fans. The thickness on each cell, $h$, was defined as the mean value 


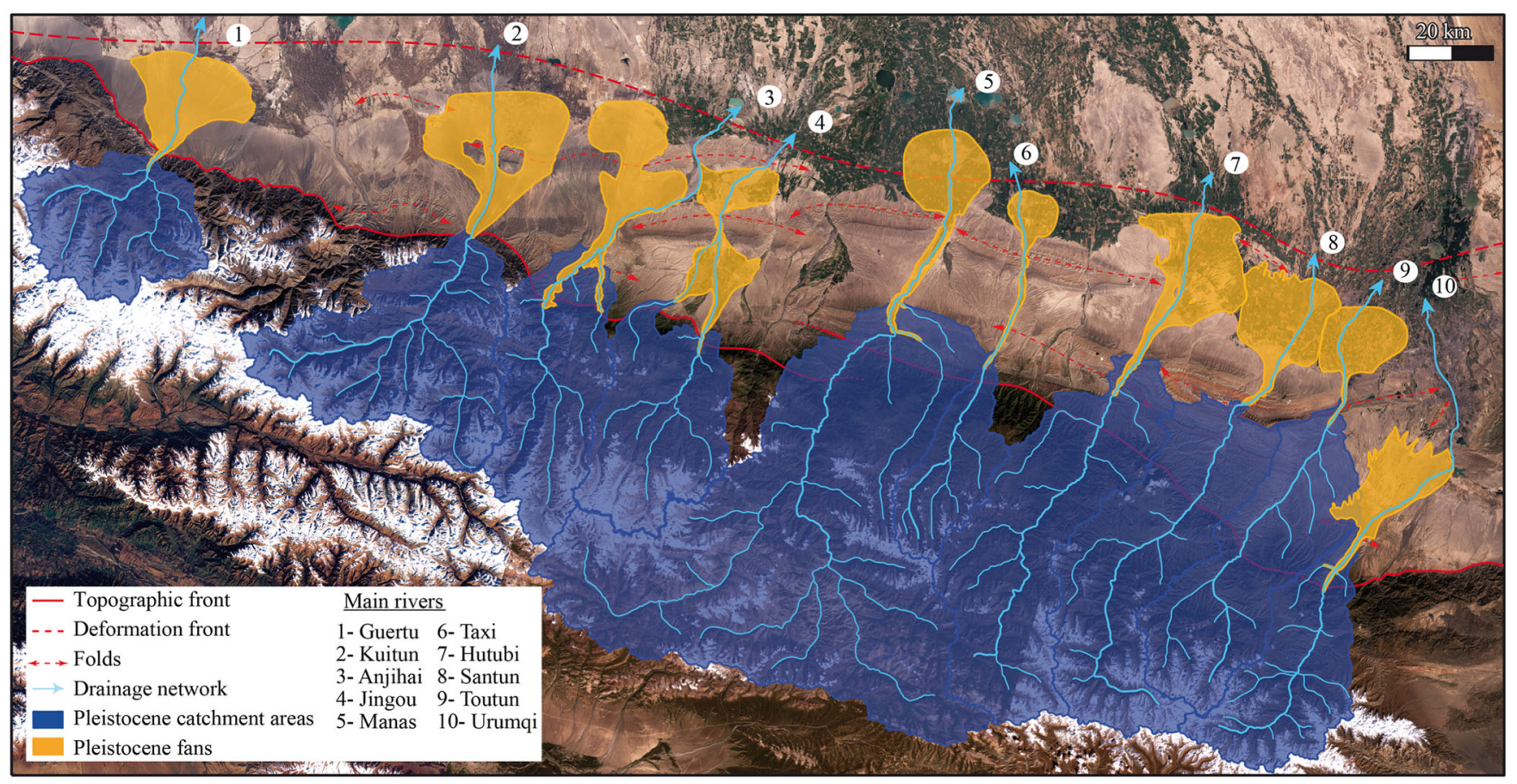

Figure 4. Late Pleistocene morpho-sedimentary map of the northern side of the Chinese Tian Shan. The Middle-Late Pleistocene fans $\mathrm{F}_{p}$ (in orange) are presented with their catchment areas (in dark blue). See text for details about the map construction. This figure is available in colour online at www.interscience.wiley.com/journal/espl.

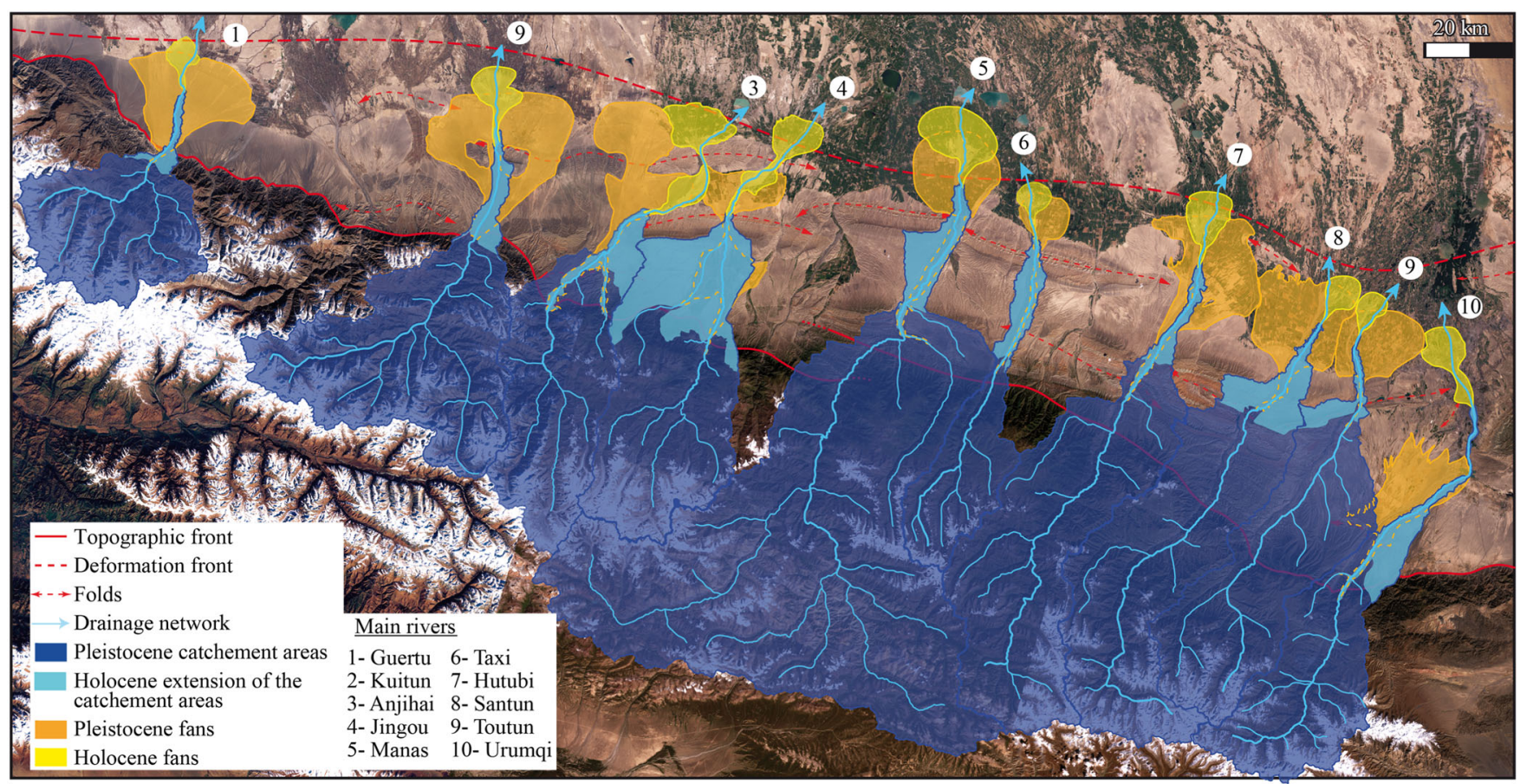

Figure 5. Present-day morpho-sedimentary map of the northern side of the Chinese Tian Shan. The Holocene fans $F_{h}$ (in yellow) are presented with their catchment areas (long-standing part in dark blue and Holocene extension in light blue). See text for details about the map construction. This figure is available in colour online at www.interscience.wiley.com/journal/espl.

obtained by the two interpolation methods. The total volume of a fan, $V_{F}$, was calculated by the addition of the individual volumes of each cell (Tables II and III; Figure 6e, f). The volume of sediments trapped in fans, $V_{\lambda F}$, is then the volume $V_{F}$ corrected for the porosity of the deposits $\lambda$ (Tables II and III; see Appendix B.2 for details on the volume reconstruction and uncertainties). As the simplest geometry was used to reconstruct the $F_{h}$ basal surfaces (i.e. a sharp transition between the $F_{p}$ fan and plain slopes), Holocene volumes correspond to maximum estimates.

\section{From sediment volumes to denudation rates}

The denudation rate, $\epsilon$, of a given area was calculated from the volume of sediments trapped in the associated fan $V_{\lambda F}$ through a simple mass conservation law:

$$
\epsilon=\frac{V_{\lambda F}}{\alpha \times A_{d} \times P}
$$

where $\alpha$ is the proportion of river sediment load trapped in the fan, $A_{d}$ is the drainage basin area of interest, and $P$ is the 
Table II. Morpho-sedimentary parameters of the Middle-Late Pleistocene catchment-fan systems. $A_{d p}$ is the catchment area, $A_{F_{p}}$ the fan area, $V_{F_{p}}$ the fan volume, and $V_{\lambda F_{p}}$ the volume of sediments trapped in the fan. $\Delta$ are the uncertainties associated with each parameter

\begin{tabular}{lrrrrrrrr}
\hline $\begin{array}{l}\text { River } \\
(\text { W to E) }\end{array}$ & $\begin{array}{c}A_{d p} \\
\left(\mathrm{~km}^{2}\right)\end{array}$ & $\begin{array}{r}\Delta A_{d p} \\
\left(\mathrm{~km}^{2}\right)\end{array}$ & $\begin{array}{c}A_{F_{p}} \\
\left(\mathrm{~km}^{2}\right)\end{array}$ & $\begin{array}{c}\Delta A_{F_{p}} \\
\left(\mathrm{~km}^{2}\right)\end{array}$ & $\begin{array}{c}V_{F_{p}} \\
\left(\mathrm{~km}^{3}\right)\end{array}$ & $\begin{array}{r}\Delta V_{F_{p}} \\
\left(\mathrm{~km}^{3}\right)\end{array}$ & $\begin{array}{r}V_{\lambda F_{p}} \\
\left(\mathrm{~km}^{3}\right)\end{array}$ & $\begin{array}{c}\Delta V_{\lambda F_{p}} \\
\left(\mathrm{~km}^{3}\right)\end{array}$ \\
\hline Guertu & 1056 & 8 & 419 & 4 & 13 & 0.7 & 10.4 & 1.6 \\
Kuitun & 1926 & 14 & 597 & 7 & 29.2 & 0.6 & 23.4 & 2.8 \\
Anjihai & 1340 & 10 & 471 & 4 & 14.4 & 0.6 & 11.5 & 1.6 \\
Jingou & 1321 & 10 & 336 & 4 & 6.4 & 0.4 & 5.1 & 0.8 \\
Manas & 5356 & 40 & 381 & 4 & 9.1 & 0.2 & 7.3 & 0.9 \\
Taxi & 632 & 5 & 141 & 2 & 3.2 & 0.0 & 2.6 & 0.3 \\
Hutubi & 2150 & 16 & 480 & 5 & 15.7 & 0.6 & 12.6 & 1.8 \\
Santun & 1996 & 15 & 416 & 5 & 8.3 & 0.3 & 6.6 & 0.9 \\
Toutun & 1597 & 12 & 264 & 2 & 7.7 & 0.1 & 6.2 & 0.7 \\
Urumqi & 1115 & 8 & 323 & 2 & 5.2 & 0.1 & 4.2 & 0.5 \\
Average & $\mathbf{1 8 5 0}$ & $\mathbf{1 4}$ & $\mathbf{3 8 3}$ & $\mathbf{4}$ & $\mathbf{1 1 . 2}$ & $\mathbf{0 . 4}$ & $\mathbf{9 . 0}$ & $\mathbf{1 . 2}$ \\
\hline
\end{tabular}

Table III. Morpho-sedimentary parameters of the Holocene catchment-fan systems. $Q_{w}$ is the present-day river average annual discharge, $A_{d h}$ the catchment area, $A_{F_{h}}$ the fan area, $V_{F_{h}}$ the fan volume and $V_{\lambda F_{h}}$ the volume of sediments trapped in the fan. $\Delta$ are the uncertainties associated with each parameter

\begin{tabular}{|c|c|c|c|c|c|c|c|c|c|}
\hline $\begin{array}{l}\text { River } \\
\text { (W to E) }\end{array}$ & $\begin{array}{c}Q_{w} \\
\left(\mathrm{~m}^{3} / \mathrm{s}\right)\end{array}$ & $\begin{array}{c}A_{d h} \\
\left(\mathrm{~km}^{2}\right)\end{array}$ & $\begin{array}{l}\Delta A_{d h} \\
\left(\mathrm{~km}^{2}\right)\end{array}$ & $\begin{array}{c}A_{F_{h}} \\
\left(\mathrm{~km}^{2}\right)\end{array}$ & $\begin{array}{l}\Delta A_{F h} \\
\left(\mathrm{~km}^{2}\right)\end{array}$ & $\begin{array}{c}V_{F_{h}} \\
\left(\mathrm{~km}^{3}\right)\end{array}$ & $\begin{array}{l}\Delta V_{F_{h}} \\
\left(\mathrm{~km}^{3}\right)\end{array}$ & $\begin{array}{l}V_{\lambda F_{h}} \\
\left(\mathrm{~km}^{3}\right)\end{array}$ & $\begin{array}{l}\Delta V_{\lambda F_{h}} \\
\left(\mathrm{~km}^{3}\right)\end{array}$ \\
\hline Guertu & / & 1111 & 8 & 45 & 1 & 0.4 & 0.1 & 0.3 & 0.1 \\
\hline Kuitun & 20 & 2049 & 15 & 98 & 1 & 2.4 & 0.3 & 1.9 & 0.4 \\
\hline Anjihai & 9.8 & 1512 & 11 & 189 & 2 & 3.6 & 0.5 & 2.9 & 0.7 \\
\hline Jingou & 10.2 & 1906 & 14 & 133 & 1 & 2 & 0.3 & 1.6 & 0.4 \\
\hline Manas & 40.5 & 5594 & 42 & 182 & 1 & 1.8 & 0.2 & 1.4 & 0.3 \\
\hline Taxi & 7.2 & 782 & 6 & 46 & 1 & 0.7 & 0.1 & 0.6 & 0.1 \\
\hline Hutubi & 15.1 & 2275 & 17 & 102 & 1 & 1.1 & 0.1 & 0.9 & 0.1 \\
\hline Santun & 9.9 & 2250 & 17 & 57 & 1 & 0.6 & 0.0 & 0.5 & 0.0 \\
\hline Toutun & 7.4 & 1701 & 13 & 43 & 1 & 1 & 0.0 & 0.8 & 0.1 \\
\hline Urumqi & 7.5 & 1318 & 10 & 102 & 1 & 1.2 & 0.1 & 1.0 & 0.2 \\
\hline Average & 14.2 & 2050 & 15 & 100 & 1 & 1.5 & 0.2 & 1.2 & 0.3 \\
\hline
\end{tabular}

duration of the fan construction (see Appendix $C$ for details on the denudation rate uncertainties).

As the fans are made up of conglomerates (i.e. typical bedload deposits), we considered that they have trapped all the bedload sediments transported by the rivers. A value of $17.3 \pm 0.3 \%$ was thus used for $\alpha$ on the basis of the only sediment load measurements performed in the region (Liu et al., 2011).

As the rivers have deeply incised the piedmont at the onset of the Holocene (Figure 8), a large amount of matter has been removed from the fans $F_{p}$ to feed the fans $F_{h}$. This contribution to the sediment fluxes is not negligible. For example, Jolivet et al. (2014) have suggested that the Holocene fan of the Kuitun River could be entirely made up of sediments reworked from the piedmont. Therefore, the volume of sediments issued from the piedmont during the Holocene and from the long-standing part of the catchment areas (the one inside the range, which already existed at the end of the Pleistocene) must be estimated to characterize the evolution of the denudation rates of the range through time. The volumes of sediments recycled from the piedmont correspond to the volumes of the canyons excavated by the rivers. As the incisions are deep and vertical (of the order of several hundred metres; Figure 8), we regarded the canyon cross-sections as rectangular and did not include the uppermost terraces. This implies that the reconstructed volumes of the canyons are minimum estimates.
The average length, width and depth of these structures were measured from the DEM and used to calculate the corresponding volumes $V_{c}$ (Table IV). These volumes were corrected for the sediment porosity to assess the volumes of matter, $V_{\lambda c}$, reworked from the canyons (Table IV). As a major part of the incised deposits corresponds to conglomerates of the fans $F_{p}$, the same porosity $\lambda$ of $20 \pm 10 \%$ was used. It was possible to propose a Holocene denudation rate in the piedmont resulting from this sediment recycling based on the volumes $V_{\lambda c}$ divided by the areas of the Holocene drainage basin extensions, $A_{d, h-p}$ (i.e. the Holocene catchment areas minus the Late Pleistocene ones), and the incision duration, $P_{h}$. In addition, the volumes of matter reworked from the canyons were also subtracted from the volumes of sediments trapped in fans $F_{h}$ in order to estimate the remaining volumes of sed-

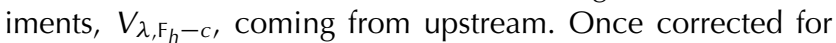
the sediment partitioning, these volumes were used to calculate the denudation rates of the long-standing parts of the catchment areas.

The same process of incision and reworking could have happened when the fans older than the Middle-Late Pleistocene ones were abandoned, but no information exists on that point. Accordingly, the volumes of sediments trapped in the fans $\mathrm{F}_{p}$ should be considered as maximum estimates. Similarly, the volumes of sediments trapped in the fans $F_{h}$ and the volumes exported from the Holocene canyons are respectively maximized and minimized due to the geometric simplifications. In consequence, the denudation rates assessed in this study for both periods correspond to maximum values. 

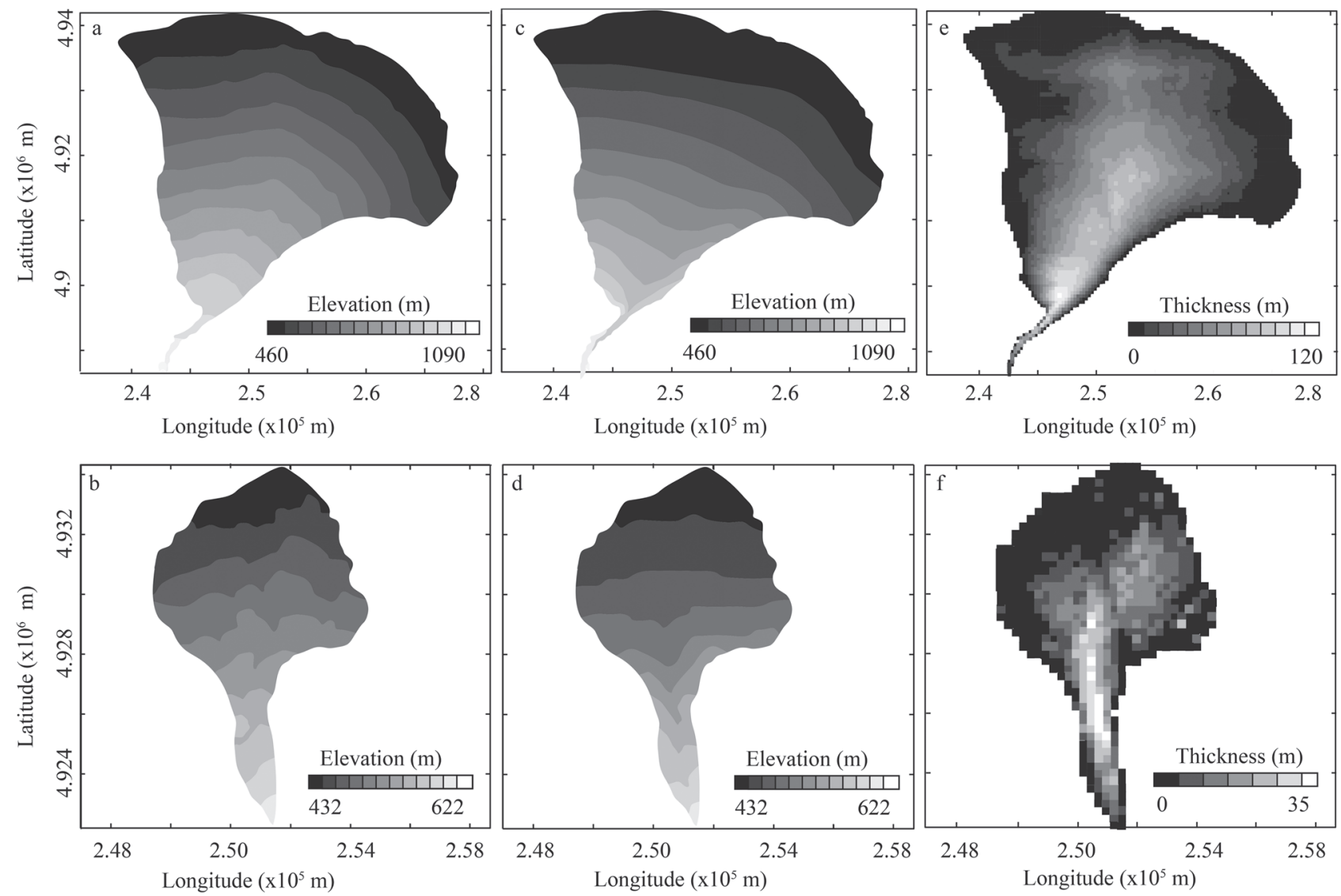

Figure 6. Example of geometric reconstructions for the fans of the Guertu River. Reconstruction of the (a, b) top surfaces, (c, d) basal surfaces and $(\mathrm{e}, \mathrm{f})$ sediment thicknesses of the Middle-Late Pleistocene and Holocene fans, respectively.
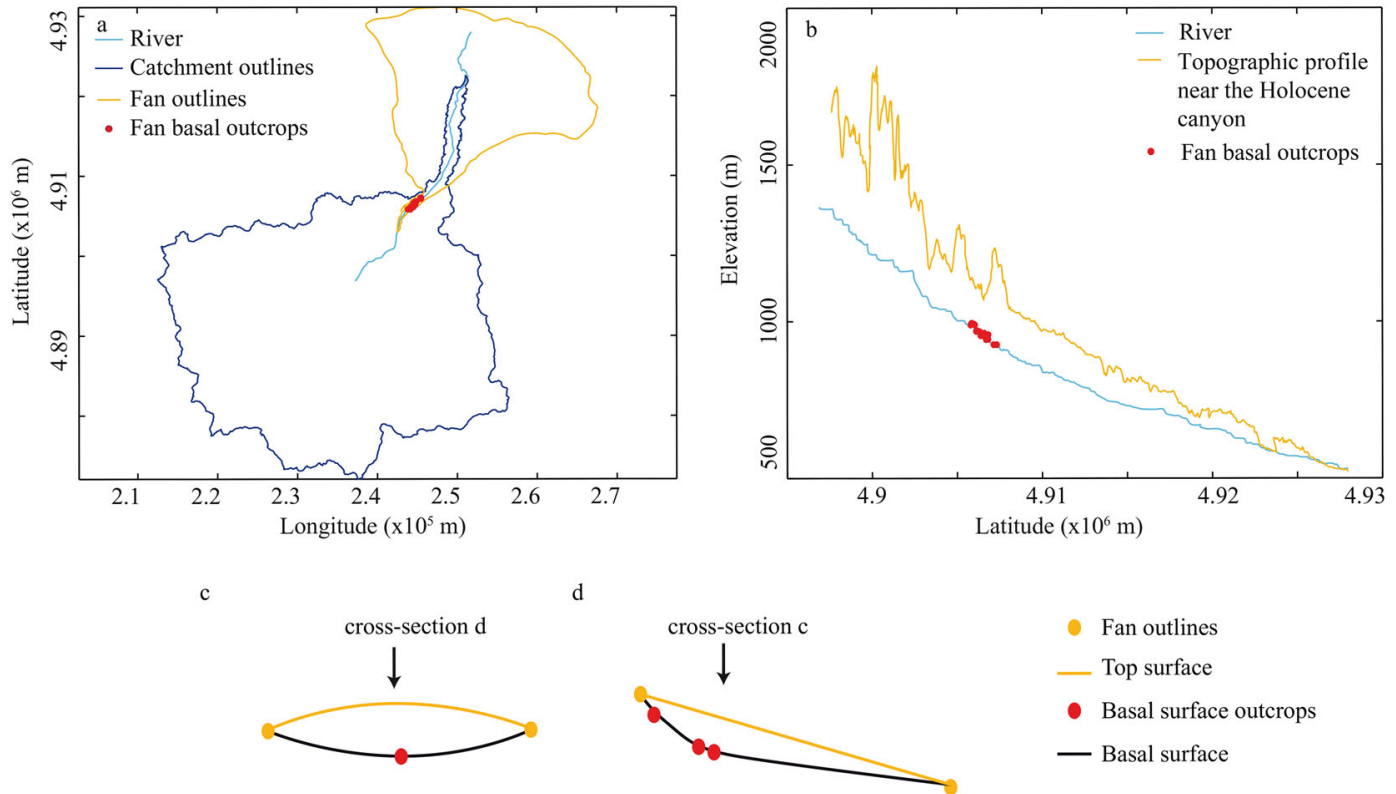

Figure 7. Location of the Middle-Late Pleistocene fan basal surface outcrops (red dots) along the Guertu River (light-blue line) (a) in plan view and (b) in cross-section. Diagrams illustrating the geometric hypothesis used to reconstruct the basal surfaces in (c) transverse and (d) longitudinal cross-sections. See text for explanation. This figure is available in colour online at www.interscience.wiley.com/journal/espl.

\section{Results}

\section{Morpho-sedimentary characteristics of the catchment-fan systems}

The two morpho-sedimentary maps (Figures 4 and 5) focus on the 10 catchment-fan systems for which the basal surface of the Middle-Late Pleistocene fans $F_{p}$ could be identified in the field, namely from west to east: the Guertu, Kuitun, Anjihai, Jingou, Manas, Taxi, Hutubi, Santun, Toutun and Urumqi systems (called after the main stream names given in Zhou et al., 1999). These maps display features of the Late Pleistocene and present-day landscapes in the studied area, namely the fans $F_{p}$ and $F_{h}$, and the associated catchment areas with their long-standing part and their recent extension (Figures 4 and 5). In addition to the catchment-fan system outlines, the 


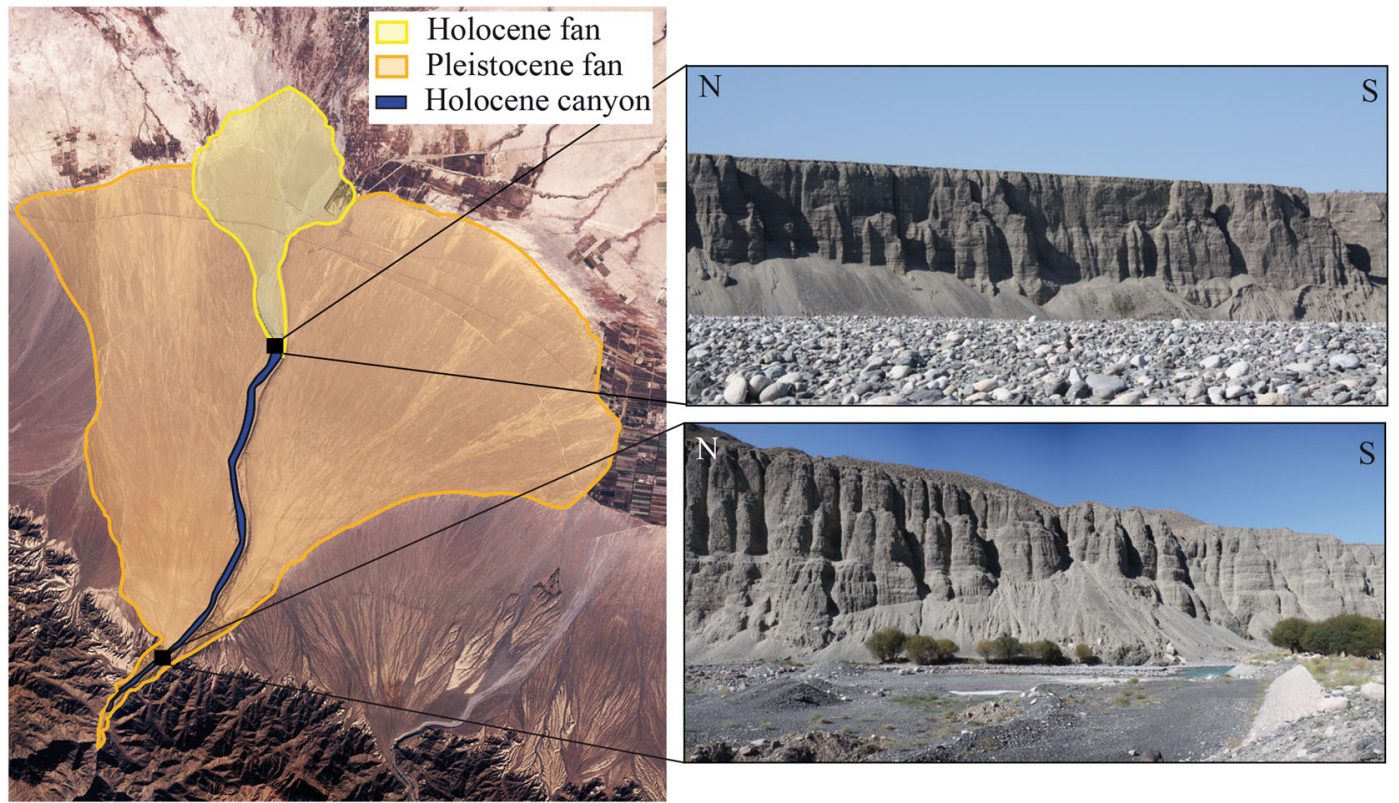

Figure 8. Morphology of the Holocene canyon of the Guertu River in map view (Landsat picture) and in lateral view (field pictures taken from the present-day river bed). The cliffs are $\sim 50 \mathrm{~m}$ high. This figure is available in colour online at www.interscience.wiley.com/journal/espl.

Table IV. Morpho-sedimentary parameters associated with the Holocene extension of the drainage basins. $A_{d, h-p}$ is the area of the Holocene drainage basin extension with the corresponding increase in percent, $V_{c}$ the volume of the Holocene canyon dug into the Middle-Late Pleistocene fan, $V_{\lambda c}$ the volume of sediments removed from the canyon and $V_{\lambda, F_{h}-c}$ the volume of sediments exported out of the range. $\Delta$ are the uncertainties associated with each parameter

\begin{tabular}{lllllllll}
\hline $\begin{array}{l}\text { River } \\
\text { (W to E) })\end{array}$ & $\begin{array}{l}A_{d, h-p} \\
\left(\mathrm{~km}^{2}\right)\end{array}$ & $\begin{array}{l}\Delta A_{d, h-p} \\
\left(\mathrm{~km}^{2}\right)\end{array}$ & $\begin{array}{l}V_{c} \\
\left(\mathrm{~km}^{3}\right)\end{array}$ & $\begin{array}{l}\Delta V_{c} \\
\left(\mathrm{~km}^{3}\right)\end{array}$ & $\begin{array}{l}V_{\lambda c} \\
\left(\mathrm{~km}^{3}\right)\end{array}$ & $\begin{array}{l}\Delta V_{\lambda c} \\
\left(\mathrm{~km}^{3}\right)\end{array}$ & $\begin{array}{l}V_{\lambda, F_{h}-c} \\
\left(\mathrm{~km}^{3}\right)\end{array}$ & $\begin{array}{l}\Delta V_{\lambda, F_{h}-c} \\
\left(\mathrm{~km}^{3}\right)\end{array}$ \\
\hline Guertu & $55(+5 \%)$ & 16 & 0.4 & 0.1 & 0.3 & 0.1 & 0 & 0.2 \\
Kuitun & $123(+6 \%)$ & 29 & 2.7 & 0.5 & 2.1 & 0.4 & 0 & 0.8 \\
Anjihai & $172(+13 \%)$ & 21 & 1.6 & 0.3 & 1.3 & 0.2 & 1.6 & 0.7 \\
Jingou & $585(+44 \%)$ & 24 & 0.6 & 0.1 & 0.5 & 0.1 & 1.1 & 0.5 \\
Manas & $238(+4 \%)$ & 82 & 0.6 & 0.1 & 0.5 & 0.1 & 0.9 & 0.4 \\
Taxi & $150(+24 \%)$ & 11 & 0.1 & 0.0 & 0.1 & 0.0 & 0.5 & 0.1 \\
Hutubi & $125(+6 \%)$ & 33 & 0.4 & 0.2 & 0.3 & 0.1 & 0.6 & 0.3 \\
Santun & $254(+13 \%)$ & 32 & 0.2 & 0.0 & 0.2 & 0.0 & 0.3 & 0.0 \\
Toutun & $104(+7 \%)$ & 25 & 0.1 & 0.0 & 0.1 & 0.0 & 0.7 & 0.1 \\
Urumqi & $203(+18 \%)$ & 18 & 0.6 & 0.1 & 0.5 & 0.1 & 0.5 & 0.2 \\
Average & $\mathbf{2 0 1 ( + 1 1 \% )}$ & $\mathbf{2 9}$ & $\mathbf{0 . 9}$ & $\mathbf{0 . 2}$ & $\mathbf{0 . 6}$ & $\mathbf{0 . 1}$ & $\mathbf{0 . 6}$ & $\mathbf{0 . 3}$ \\
\hline
\end{tabular}

topographic and deformation fronts as well as the main folds are indicated.

During the Middle-Late Pleistocene, the drainage basins are mostly located in the hinterland mountains. Their areas range from $632 \pm 5 \mathrm{~km}^{2}$ for the Taxi catchment-fan system to $5356 \pm$ $40 \mathrm{~km}^{2}$ for the Manas one, with an average area of $1850 \pm 14$ $\mathrm{km}^{2}$ (Table II). The associated alluvial fans $\mathrm{F}_{p}$ are located both in the piedmont and the foreland basin, and their areas range from $141 \pm 2 \mathrm{~km}^{2}$ for the Taxi system to $597 \pm 7 \mathrm{~km}^{2}$ for the Kuitun one, with an average of $382 \pm 4 \mathrm{~km}^{2}$ (Table II). In terms of volume, these fans store between $2.6 \pm 0.3$ and $23.4 \pm 2.8$ $\mathrm{km}^{3}$ of sediments (for the Taxi and Kuitun fans, respectively), with an average volume of $9.0 \pm 1.2 \mathrm{~km}^{3}$ (Table II). In most cases, their thickness is maximal at their apex, with up to 120 $\mathrm{m}$ thick deposits (Figure S1).

During the Holocene, the catchment areas expanded in the piedmont due to the downstream propagation of an erosion wave triggered by changes in water and/or sediment discharges (Poisson, 2002; Poisson and Avouac, 2004). Consequently, the Holocene drainage basins are larger than the
Middle-Late Pleistocene ones, ranging from $782 \pm 6 \mathrm{~km}^{2}$ for the Taxi system to $5594 \pm 42 \mathrm{~km}^{2}$ for the Manas one, with an average of $2050 \pm 42 \mathrm{~km}^{2}$ (Table III). The Holocene extensions of these drainage basins correspond to an increase in size of $4 \%$ for the Manas system and up to $44 \%$ for the Jingou one, with an average of $11 \%$ (Table IV).

Owing to the propagation of the erosion-sedimentation boundary down the river systems, the alluvial fans $F_{h}$ are mostly located in the foreland basin at the toe of the fans $\mathrm{F}_{p}$. Contrary to the catchment areas, the fans $\mathrm{F}_{h}$ are smaller than the fans $F_{p}$. Their areas range from $43 \pm 1 \mathrm{~km}^{2}$ for the Toutun fan to $189 \pm 2 \mathrm{~km}^{2}$ for the Anjihai one, with an average of $100 \pm 1 \mathrm{~km}^{2}$ (Table III). In terms of volume, they contain between $0.3 \pm 0.1$ and $2.9 \pm 0.7 \mathrm{~km}^{3}$ of sediments (for the Guertu and Anjihai fans, respectively) with an average volume of $1.2 \pm 0.3 \mathrm{~km}^{3}$ (Table III). In these fans, the sediment thickness is maximal at the slope break between the fans $F_{p}$ and the downstream alluvial plain, with up to $90 \mathrm{~m}$ thick deposits (Figure S2). 


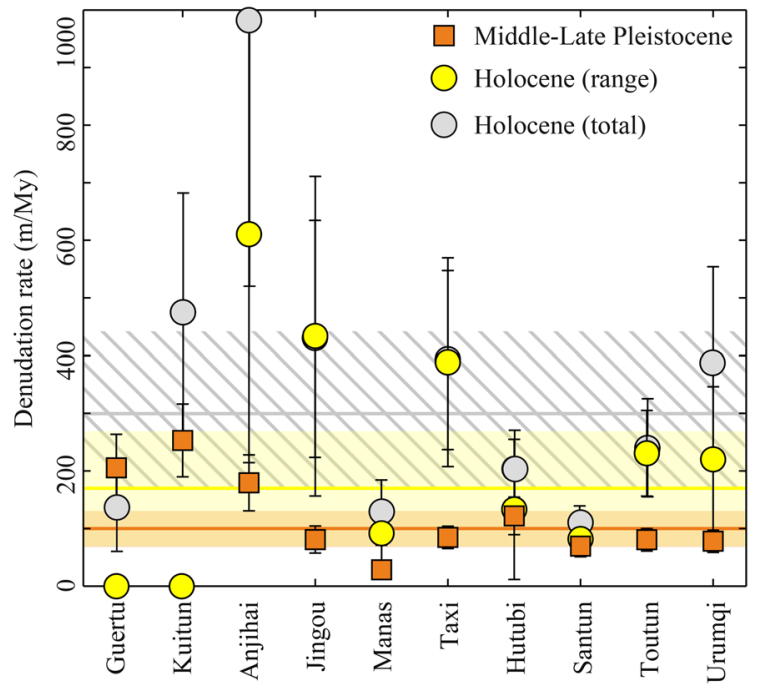

Figure 9. Denudation rates along the northern side of the Chinese Tian Shan. The Middle-Late Pleistocene denudation (orange squares) varies between $30 \pm 10$ and $250 \pm 60 \mathrm{~m} / \mathrm{Myr}$, with an average value (orange line) of $100 \pm 30 \mathrm{~m} / \mathrm{Myr}$ (Table ??). The total Holocene denudation (grey dots) varies between $130 \pm 60$ and $970 \pm 460 \mathrm{~m} / \mathrm{Myr}$, with an average value of $300 \pm 130 \mathrm{~m} / \mathrm{Myr}$ (grey line). However, the denudation in the range only (yellow dots) varies from 0 to $610 \pm 400$ $\mathrm{m} / \mathrm{Myr}$, with an average value (yellow line) of $170 \pm 110 \mathrm{~m} / \mathrm{Myr}$ (Table IV). This figure is available in colour online at www.interscience.wiley. com/journal/espl.

\section{Denudation rates}

During the Middle-Late Pleistocene

The Middle-Late Pleistocene denudation rates, $\epsilon_{p}$, were calculated as

$$
\epsilon_{p}=\frac{V_{\lambda F_{p}}}{\alpha \times A_{d p} \times P_{p}}
$$

$p$ referring to the Middle-Late Pleistocene values estimated from the morpho-sedimentary maps and from the literature (see 'Data and Methodology', above). These denudation rates range from $30 \pm 10 \mathrm{~m} /$ Myr for the Manas system to $250 \pm 60$ $\mathrm{m} /$ Myr for the Kuitun one, with an average value of $100 \pm$ $30 \mathrm{~m} /$ Myr (Table $\mathrm{V}$ and Figure 9). One may notice that $\epsilon_{p}$ varies within almost a factor of 10 between the different drainage basins.

\section{During the Holocene}

The total denudation rates for the Holocene, $\epsilon_{h}$, were calculated as follows:

$$
\epsilon_{h}=\frac{V_{\lambda F_{h}}}{\alpha \times A_{d h} \times P_{h}}
$$

${ }_{h}$ referring to the Holocene values. These total rates range from $110 \pm 40 \mathrm{~m} / \mathrm{Myr}$ for the Santun system to $970 \pm 460 \mathrm{~m} / \mathrm{My}$ for the Anjihai one, with an average value of $300 \pm 130 \mathrm{~m} / \mathrm{Myr}$ (Table $V$ and Figure 9). Here again, a factor of 10 is observed between the different rates. However, to discuss the evolution of the denudation rates from the Middle-Late Pleistocene to the Holocene, the denudation in the piedmont must be differentiated from the denudation in the mountain range.

The denudation rates in the piedmont, $\epsilon_{c}$, were calculated as the volumes of sediments removed from the canyons artificially spread over the Holocene extensions of the drainage basins:

$$
\epsilon_{c}=\frac{V_{\lambda c}}{A_{d, h-p} \times P_{h}}
$$

As these rates are calculated from eroded volumes and not from deposited ones, $\alpha$ is not required in this equation. Values range from $60 \pm 20 \mathrm{~m} /$ Myr for the Taxi system to $1550 \pm 780$ $\mathrm{m} /$ Myr for the Kuitun one with, on average, $260 \pm 130 \mathrm{~m} / \mathrm{Myr}$ (Table V). On the other hand, considering the remaining volumes of sediments in the fans $F_{h}$ and the long-standing part of the drainage basins, the denudation rates in the range, $\epsilon_{r}$, were calculated as follows:

$$
\epsilon_{r}=\frac{V_{\lambda, F_{h}-c}}{\alpha \times A_{d p} \times P_{h}}
$$

These denudation rates range from $0 \mathrm{~m} / \mathrm{Myr}$ for the Guertu and Kuitun systems to $610 \pm 400 \mathrm{~m} / \mathrm{Myr}$ for the Anjihai one, with an average value of $170 \pm 110 \mathrm{~m} / \mathrm{Myr}$ (Table V and Figure 9).

The Holocene denudation in the piedmont results from sediment reworking linked to the river incision at the onset of the last deglaciation, which is a local and probable short-term contribution. The denudation in the range should be more representative of the regional and long-term rate and is therefore the relevant value to compare the Middle-Late Pleistocene and Holocene periods. It did not noticeably evolve through time, with average values weighted by the drainage areas of $100 \pm 30 \mathrm{~m} /$ Myr and $170 \pm 100 \mathrm{~m} /$ Myr respectively (Figure 9).

Finally, these calculations lead to an average denudation rate of $\sim 135 \mathrm{~m} / \mathrm{Myr}$ for the northern Tian Shan for the last $300 \mathrm{kyr}$. Since the sediment volumes have systematically been maximized, this rate is a maximum estimate.

\section{Discussion}

\section{Catchment-fan mass balance}

Denudation rates issued from catchment-fan mass balances are subject to several sources of uncertainty. In addition to the volumes of sediments and areas of the drainage basins, the duration of fan construction $P$ and the fraction of the river sediment load trapped in the fans $\alpha$ must be determined. In most cases, the volumes and areas, as well as their uncertainties, can be accurately quantified. In this study, these uncertainties related to the geometry of the system are very small (less than $2 \%$ ) and could have been neglected. In contrast, the values of $P$ and $\alpha$ are not so well constrained because they require strong field efforts and access to the whole drainage system to be characterized.

The published time constraints for the northern side of the Chinese Tian Shan are scarce compared to the number and size of the fans (Molnar et al., 1994; Poisson, 2002; Poisson and Avouac, 2004; Lu et al., 2010; Yang et al., 2013; Gong et al., 2014). Yet the fan onset and abandonment seem to vary across space from a few thousand years and it would be important to quantify better this variability because of its potential impact on denudation rate assessment. For the Holocene, a variation of a few thousand years over $P_{h}(\sim 11.3 \mathrm{kyr})$ would imply a drop or rise of the denudation rates by a factor of up to 2. On the contrary, for the Middle-Late Pleistocene, this variability has no major impact on the determination of the denudation rates as it is an order of magnitude smaller than $\mathrm{P}_{p}(\sim 277 \mathrm{kyr})$.

The sediment partitioning, which is quite difficult to estimate, is the other main critical parameter in such mass balance studies. In this work, we considered that the alluvial fans are built by the deposition of the entire bedload. The only data available in the region were used to define the fraction of sediments transported as bedload $(\sim 17 \%)$ compared to the total river load (Liu et al., 2011). As the potential variation from 
Table V. Denudation rates for the 10 catchment-fan systems considered in this study. $\epsilon_{p}$ is the Middle-Late Pleistocene denudation rate in the range, $\epsilon_{h}$ the total Holocene denudation rate, $\epsilon_{c}$ the Holocene denudation rate in the piedmont and $\epsilon_{r}$ the Holocene denudation rate in the range. Values are rounded to the nearest tenth and averages are pondered by the drainage areas. $\Delta$ are the uncertainties associated with each parameter

\begin{tabular}{lccccrrrr}
\hline $\begin{array}{l}\text { River } \\
\text { (W to E) }\end{array}$ & $\begin{array}{c}\epsilon_{p} \\
(\mathrm{~m} / \mathrm{Myr})\end{array}$ & $\begin{array}{c}\Delta \epsilon_{p} \\
(\mathrm{~m} / \mathrm{Myr})\end{array}$ & $\begin{array}{c}\epsilon_{h} \\
(\mathrm{~m} / \mathrm{Myr})\end{array}$ & $\begin{array}{c}\Delta \epsilon_{h} \\
(\mathrm{~m} / \mathrm{Myr})\end{array}$ & $\begin{array}{c}\boldsymbol{\epsilon}_{c} \\
(\mathrm{~m} / \mathrm{Myr})\end{array}$ & $\begin{array}{c}\Delta \boldsymbol{\epsilon}_{c} \\
(\mathrm{~m} / \mathrm{Myr})\end{array}$ & $\begin{array}{c}\boldsymbol{\epsilon}_{r} \\
(\mathrm{~m} / \mathrm{Myr})\end{array}$ & $\begin{array}{c}\Delta \boldsymbol{\epsilon}_{r} \\
(\mathrm{~m} / \mathrm{Myr})\end{array}$ \\
\hline Guertu & 210 & 60 & 150 & 90 & 510 & 290 & 0 & 20 \\
Kuitun & 250 & 60 & 480 & 220 & 1550 & 780 & 0 & 50 \\
Anjihai & 180 & 50 & 970 & 460 & 660 & 330 & 610 & 400 \\
Jingou & 80 & 20 & 430 & 210 & 70 & 40 & 430 & 280 \\
Manas & 30 & 10 & 130 & 60 & 180 & 90 & 90 & 60 \\
Taxi & 80 & 20 & 370 & 170 & 50 & 20 & 390 & 180 \\
Hutubi & 120 & 30 & 200 & 80 & 220 & 190 & 130 & 120 \\
Santun & 70 & 20 & 110 & 40 & 60 & 20 & 80 & 30 \\
Toutun & 80 & 20 & 240 & 80 & 70 & 20 & 230 & 80 \\
Urumqi & 80 & 20 & 370 & 150 & 210 & 100 & 220 & 130 \\
Average & $\mathbf{1 0 0}$ & $\mathbf{3 0}$ & $\mathbf{3 0 0}$ & $\mathbf{1 3 0}$ & $\mathbf{2 6 0}$ & $\mathbf{1 3 0}$ & $\mathbf{1 7 0}$ & $\mathbf{1 1 0}$ \\
\hline
\end{tabular}

one basin to another could not be quantified, uncertainty on this ratio relates to measurements only. However, other studies on gravel-bed rivers indicate that the bedload can represent $10-50 \%$ of their total load (Lane and Borland, 1951; Meunier et al., 2006; Schiefer et al., 2010). With such ratios, the average denudation rate of the northern Tian Shan since 300 kyr could be between 50 and $230 \mathrm{~m} / \mathrm{Myr}$. It is also possible that fans are built by a fraction of the total load that does not correspond exactly to the entire bedload. Studies on sediment partitioning in alluvial systems suggest that $25-80 \%$ of the solid load of a river can be deposited in alluvial fans (Kiefer et al., 1997; Oguchi, 1997; Jolivet et al., 2014). In the Urumqi River, the solid load represents $\sim 53 \%$ of the total load (Liu et al., 2011). Extrapolating this ratio to the other rivers of the piedmont implies that the fans could have trapped $\sim 12-38 \%$ of the total load. With such ratios, the average denudation rate could be between 60 and $200 \mathrm{~m} / \mathrm{Myr}$.

Further work is thus strongly required to determine better the sediment transport and partitioning in alluvial systems. Yet, in the northern Tian Shan, the values discussed previously show that the average denudation rate cannot exceed a few hundreds of metres per million years for the last $300 \mathrm{kyr}$.

\section{Denudation in the northern Chinese Tian Shan}

At a local scale, the catchment-fan mass balances show that the denudation rate varies from one drainage basin to another (Figure 9) but it is difficult to understand what controls this variability. It could result from changes in space of the forcing factors, but the potential variations of tectonic and climatic conditions over the studied area are not known. Therefore, their influence on the denudation variability cannot be discussed. Instead, the relationship between denudation rates and some geomorphic characteristics of the drainage basins can be studied, such as the drainage area, mean elevation, mean slope and channel steepness index. These parameters are generally considered as proxies in a broad way for sediment production and transport (e.g. Ahnert, 1970; Summerfield and Hulton, 1994; Hovius, 1998; von Blanckenburg, 2005). However, the correlation between denudation rates and basin morphometrics in the northern Tian Shan is poor (Figure S3). Such a scattering could be due to differences in bedrock properties (e.g. in lithology, fracturing, dip, foliation) and erodibility, vegetation cover, glacial processes and/or sediment transport efficiency (e.g. de Vente et al., 2007; Insel et al., 2010; Norton et al., 2011; Torres Acosta et al., 2015). In the studied area, these factors are likely to vary from one drainage basin to another with, for example, different proportions of Palaeozoic igneous rocks, Palaeozoic carbonates and Meso-Cenozoic clastic sediments affected by a more or less complex tectonic history. Vegetation could also vary a lot with different proportions of bare rock/soils, herbaceous plants and trees that could influence the sediment production and transport. In addition, denudation rates could be influenced by glacial erosion or morphological heritage, as well as sediment storage that has been evidenced in the drainage basins (Li et al., 2001; Jolivet et al., 2014). Unfortunately, these basins are poorly accessible and all those factors are very difficult to quantify in this region. Finally, changes in sediment production, transport and deposition should also influence the sediment partitioning, and therefore, $\alpha$ might vary from one catchment area to another. The determination of this parameter for all the basins over the considered periods could be a way to assess whether or not differences in the parameters mentioned previously (e.g. lithology, vegetation) are the sources of the denudation variability. However, to date, there is no method to perform such measurement. Further work would be of interest to understand better what influence catchment-fan mass balance and the denudation rates at the local scale.

At a regional scale, the average denudation rate in the mountain range seems to be around $135 \mathrm{~m} /$ Myr for the last 300 kyr. This value is in good agreement with previous mass balance estimates performed at different scales (Figure 10). Using the same approach applied to one Holocene catchment-fan system and on the solid sediment load only, Jolivet et al. (2014) suggest a rate lower than $100 \mathrm{~m} / \mathrm{Myr}$ for the last 12 kyr. From a sediment budget over the whole Junggar basin, Métivier and Gaudemer (1997) propose a long-term regional denudation of $\sim 40 \mathrm{~m} / \mathrm{Myr}$ since 6 Myr. From sediment load measurements in one river during 2 years, Liu et al. (2011) determine a short-term and local denudation of $\sim 20 \mathrm{~m} / \mathrm{Myr}$. Studies in the same area based on cosmogenic analysis point toward higher average values of 200 to $600 \mathrm{~m} / \mathrm{Myr}$ for the last 8 Myr (Charreau et al., 2011; Puchol, 2013). However, cosmogenic concentrations are influenced by the distribution of the sources or of the samples in the drainage basin (nearby an active fault or a glacier), by the story of the sediment transport and also by a possible unsteady erosion that could lead to maximize denudation rates (Jolivet et al., 2014; Carretier et al., 2015). Finally, basement-derived fission track ages indicate 


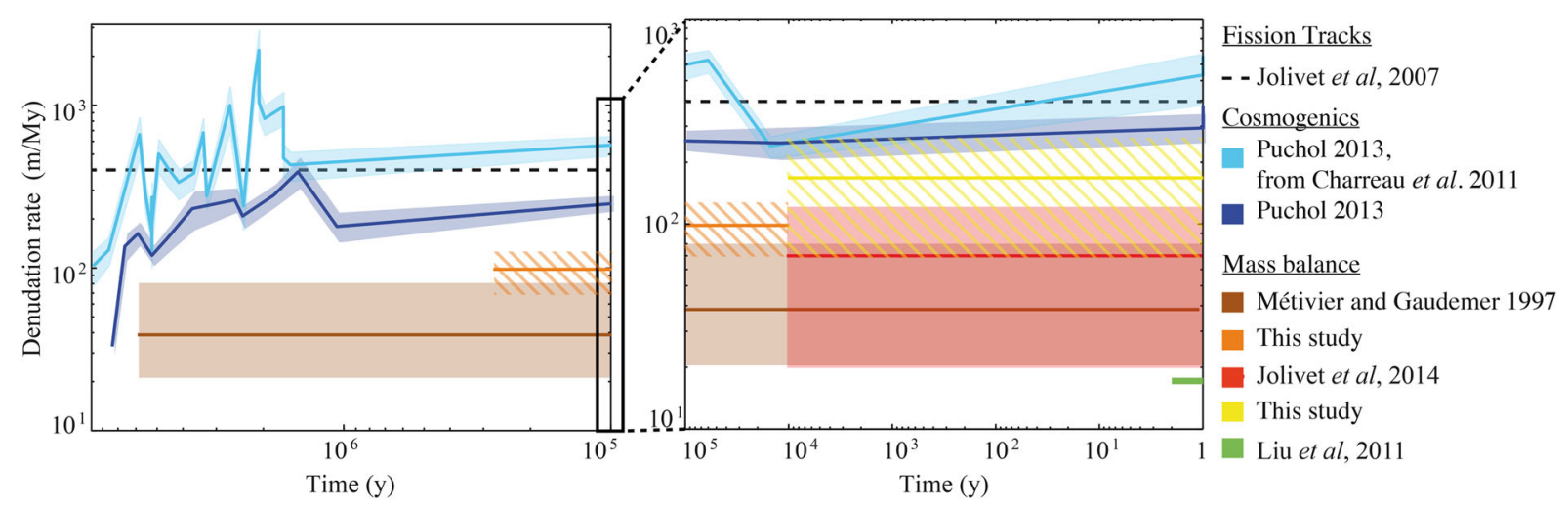

Figure 10. Existing estimates for denudation rates of the northern side of the Chinese Tian Shan (from (Jolivet et al., 2007; Métivier and Gaudemer, 1997; Charreau et al., 2011; Liu et al., 2011; Puchol, 2013; Jolivet et al., 2014); this study). This figure is available in colour online at www. interscience.wiley.com/journal/espl.

that the northern Tian Shan (Borohoro range) rose between 15 and $10 \mathrm{Ma}$ ago (Dumitru et al., 2001; Jolivet et al., 2010). Considering a maximum geothermal gradient of $30 \circ \mathrm{C} / \mathrm{km}$, these ages correspond to $4 \mathrm{~km}$ of rock exhumation, leading to an average erosion of $260-400 \mathrm{~m} / \mathrm{Myr}$ for this period (Figure 10). However, erosion rates derived from apatite fission track data rely largely on the understanding of the geothermal gradient and the behaviour of the isotherms (i.e. their capacity to re-equilibrate) during tectonic deformation (e.g. Ehlers and Farley, 2003). In other words, the rates determined by cosmogenic and thermochronological methods in the Tian Shan might correspond to maximum possible values. Consequently, only the values determined by mass balances are considered in this study to determine the average denudation rate for this range. They all converge toward a few hundreds of metres per million years at maximum regardless of the space or time scale.

\section{Influence of tectonics and climate}

For the whole northern side of the Tian Shan (range and piedmont), the average denudation rate rises from $\sim 100 \mathrm{~m} / \mathrm{Myr}$ during the Middle-Late Pleistocene to $\sim 300 \mathrm{~m} / \mathrm{Myr}$ during the Holocene (Table $V$ and Figure 9). This increase is a direct consequence of the downstream extension of the catchment areas associated with sediment reworking due to the last glacial-interglacial transition (Molnar et al., 1994; Poisson, 2002; Poisson and Avouac, 2004; Lu et al., 2010; Gong et al., 2014). Over the last $300 \mathrm{kyr}$, the evolution of the sediment fluxes from the Tian Shan to the Junggar Basin is thus clearly climate-driven, as observed in other places at the same period (Church and Ryder, 1972; Church and Slaymaker, 1989; Delmas et al., 2015). However, once corrected for this sediment recycling, the average denudation rates in the long-standing part of the drainage basins are quite similar for the two periods $(\sim 100$ and $\sim 170 \mathrm{~m} / \mathrm{Myr})$. The consistency between these rates and those previously published (Métivier and Gaudemer, 1997; Charreau et al., 2011; Liu et al., 2011; Puchol, 2013; Jolivet et al., 2014) suggests that the pulse observed at the onset of the Holocene is a local and transient feature associated with a major morphological evolution that did not affect the denudation of the hinterland mountains (see also ; Jolivet et al., 2014).

As mentioned previously, an average rate of a few hundred metres per million years seems to be more representative of the denudation intensity in the mountain range whatever the considered space and time scales. This rate is quite low for a high and active mountain belt like the northern Tian
Shan, as it is closer to the rates observed in the flat Middle Europe (Schaller et al., 2001; Hoffmann et al., 2007) than to those observed in the Himalayas (Bhutiyani, 2000; Galy and France-Lanord, 2001; Grujic et al., 2006; Vance et al., 2003) (Table VI). To discuss whether this low rate is controlled by tectonics or climate, recent shortening rate and precipitations can be used as respective proxies for the two forcings in different mountain ranges throughout the world. Recent shortening rate in the Chinese Tian Shan is around $\sim 1 \mathrm{~cm} / \mathrm{yr}$ (Reigber et al., 2001; Champagnac et al., 2012) and seems to have been stable for the last million years (Avouac et al., 1993; Burtman et al., 1996; Burchfiel et al., 1999; Charreau et al., 2009b). Present-day precipitation is around $300 \mathrm{~mm} / \mathrm{yr}$ (Métivier and Gaudemer, 1997; Poisson, 2002; Sobel et al., 2003). Their amount might have varied over the last million years since alternations of drier and wetter periods are documented in the region at different time scales (Molnar et al., 1994; Rhodes et al., 1996; Poisson and Avouac, 2004; Yi et al., 2004; Gallaud, 2008; Xu et al., 2010). However, in spite of these variations, the average denudation rate is always low (i.e. less than a few hundred metres per million years) whatever the time scale over which it is integrated: 2 years (Liu et al., 2011), the Holocene (Jolivet et al., 2014, and this study), the last 300 kyr (this study) or a few million years (Metivier and Gaudemer, 1999; Charreau et al., 2011).

First, the denudation rates according to the shortening rates are compared in ranges where the precipitation rates are equivalent ( $300 \mathrm{~mm} / \mathrm{yr}$; Table VI and Figure 11a). Denudation rates increase slightly with the shortening rate (from $\sim 30$ to $\sim 135 \mathrm{~m} / \mathrm{Myr}$ ), but stay within the same order of magnitude. In these semi-arid areas, the denudation rate is systematically low. Next, the denudation rates according to the annual precipitation rates are compared in ranges where the shortening rates are equivalent $(\sim 1 \mathrm{~cm} / \mathrm{yr}$; Table $\mathrm{VI}$ and Figure 11b), excluding orogenic plateaus to avoid a topographic bias. Two groups clearly appear: (i) ranges with limited rainfall $(<1000$ $\mathrm{mm} / \mathrm{yr})$, where the denudation rates are low $(\sim 100 \mathrm{~m} / \mathrm{Myr})$; versus (ii) ranges with higher precipitations (>1000 mm/yr), where the denudation rates are one order of magnitude higher $(>1000 \mathrm{~m} / \mathrm{Myr})$. In other words, an increase of one order of magnitude in the shortening rate in a semi-arid climate induces a limited change of the denudation rate. On the contrary, a rise of one order of magnitude in the precipitation rate in equivalent shortening velocity areas induces a similar increase of the denudation rate. Therefore, we propose that the low denudation rate observed in the Tian Shan is due to the aridity of the region.

Dry climatic conditions are attested in this area for longer than the period documented for the denudation. The Cenozoic 
Table VI. Precipitation, shortening and denudation rates of some mountain ranges over the world

\begin{tabular}{|c|c|c|c|c|}
\hline Setting & $\begin{array}{l}\text { Precipitations } \\
\quad(\mathrm{mm} / \mathrm{yr})\end{array}$ & $\begin{array}{l}\text { Shortening } \\
(\mathrm{mm} / \mathrm{yr})\end{array}$ & $\begin{array}{l}\text { Denudation } \\
(\mathrm{mm} / \mathrm{yr})\end{array}$ & Sources \\
\hline Southern Alps (NZ) & $7000 \pm 1000$ & $7.5 \pm 0.5$ & $7500 \pm 1500$ & $\begin{array}{l}\text { Henderson and Thompson (1999); Herman et al. } \\
\text { (2010); Norris and Toy (2014) }\end{array}$ \\
\hline East Andes & $1750 \pm 250$ & $6 \pm 2$ & $430 \pm 290$ & $\begin{array}{l}\text { Safran et al. (2005), Champagnac et al., 2012, and } \\
\text { references therein }\end{array}$ \\
\hline East Cascades & $300 \pm 100$ & $\sim 0$ & $30 \pm 10$ & Reiners et al. (2003) \\
\hline Middle Europe & $1000 \pm 500$ & $\sim 0$ & $40 \pm 20$ & Schaller et al. (2001); Hoffmann et al. (2007) \\
\hline East Himalayas & $3500 \pm 2500$ & $17 \pm 3$ & $1400 \pm 400$ & $\begin{array}{l}\text { Grujic et al. (2006), Champagnac et al., 2012, and } \\
\text { references therein }\end{array}$ \\
\hline East Himalayas & $2500 \pm 1500$ & $17 \pm 3$ & $700 \pm 150$ & $\begin{array}{l}\text { Grujic et al. (2006), Champagnac et al., } 2012 \text { and } \\
\text { references therein }\end{array}$ \\
\hline West Himalayas & $1650 \pm 150$ & $15 \pm 5$ & $\sim 1800$ & $\begin{array}{l}\text { Bhutiyani (2000); Winiger et al. (2005), } \\
\text { Champagnac et al., 2012, and references therein }\end{array}$ \\
\hline West Himalayas & $\sim 600$ & $15 \pm 5$ & $280 \pm 190$ & $\begin{array}{l}\text { Bhutiyani (2000); Winiger et al. (2005), } \\
\text { Champagnac et al., 2012, and references therein }\end{array}$ \\
\hline Qilian Shan & $275 \pm 120$ & $5.5 \pm 1.8$ & $200 \pm 100$ & $\begin{array}{l}\text { Pan et al. (2010); Palumbo et al. (2011), } \\
\text { Champagnac et al., 2012, and references therein }\end{array}$ \\
\hline Longshou Shan & $\sim 200$ & $5.5 \pm 1.8$ & $155 \pm 12$ & $\begin{array}{l}\text { Palumbo et al. (2010), Champagnac et al., 2012, } \\
\text { and references therein }\end{array}$ \\
\hline Tian Shan & $300 \pm 100$ & $10 \pm 3$ & $135 \pm 140$ & $\begin{array}{l}\text { This study, Métivier and Gaudemer, 1997; Reigber } \\
\text { et al., 2001; Sobel et al., 2003, Champagnac et } \\
\text { al., 2012, and references herein }\end{array}$ \\
\hline Zagros & $400 \pm 100$ & $8 \pm 2$ & $85 \pm 75$ & $\begin{array}{l}\text { Ali et al. (2003); Javanmard et al. (2010), } \\
\text { Champagnac et al., 2012, and references therein }\end{array}$ \\
\hline
\end{tabular}
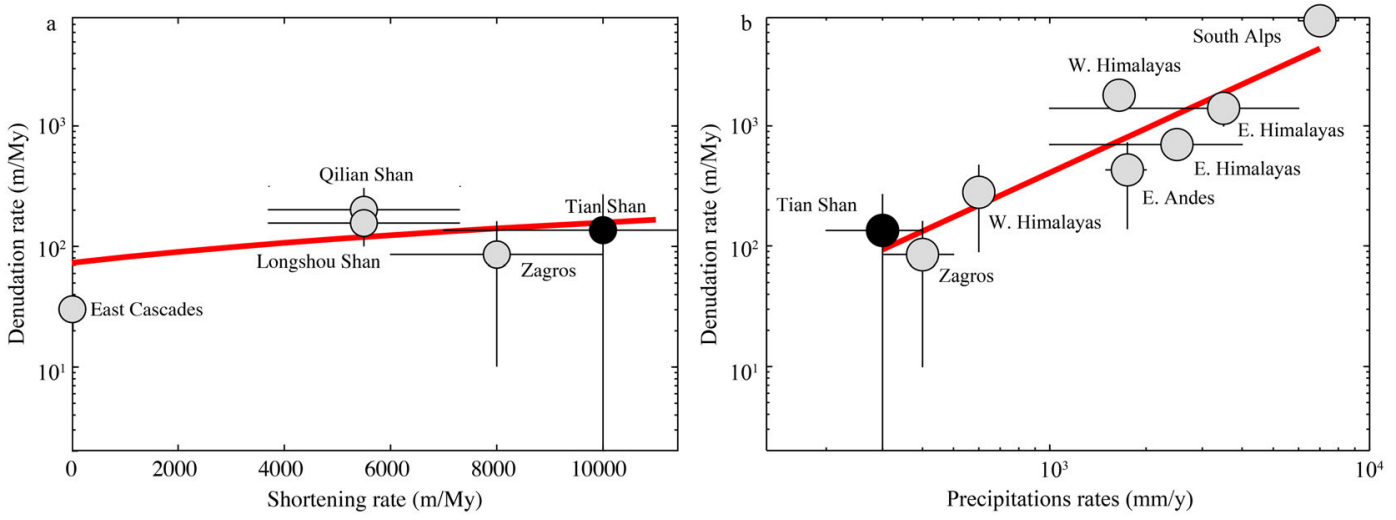

Figure 11. (a) Denudation rates according to shortening rates in mountain ranges where precipitations are close to $300 \mathrm{~mm} / \mathrm{yr}$. (b) Denudation rates according to mean annual precipitation in mountain ranges where the shortening rate is close to $1 \mathrm{~cm} / \mathrm{yr}$ (see Table VI for references). This figure is available in colour online at www.interscience.wiley.com/journal/espl.

deposits of the northern piedmont contain pedogenic carbonates (Charreau et al., 2012; Heilbronn et al., 2015), which form under semi-arid to semi-humid climate with less than $1000 \mathrm{~mm} / \mathrm{yr}$ of precipitation (Retallack et al., 1997, and references therein). This could imply that the Chinese Tian Shan has been experiencing a low denudation rate for a few tens of millions of years, which is in agreement with geological observations such as preserved Mesozoic surfaces in the mountain range and a limited Cenozoic exhumation (Hendrix et al., 1994; Dumitru et al., 2001; Jolivet et al., 2010). If equilibrium between denudation and rock uplift has been reached, it means that the tectonic uplift rate in the range is also less than a few hundred metres per million years. However, a rough estimate gives a rock uplift rate in the Chinese Tian Shan of 300-700 m/Myr (Avouac and Burov, 1996), which is several times higher than the average denudation rate of the range. It is thus possible that the range has not reached equilibrium. This implies that the response time of this orogenic system in a dry climate is extremely long. Yet, to address this issue fully, the tectonic uplift rate in the Tian Shan remains to be accurately quantified.

\section{Conclusions}

Based on mass balances performed on 10 catchment-fan systems, we determine average denudation rates for the northern Chinese Tian Shan of $\sim 100$ and $\sim 300 \mathrm{~m} / \mathrm{Myr}$ for the Middle-Late Pleistocene and Holocene, respectively. The denudation increase between the two periods is climate-driven. It is a direct consequence of the extension of the catchment areas in the piedmont associated with sediment reworking following the last glacial-interglacial transition. However, this evolution did not affect the denudation intensity of the hinterland mountains.

In fact, the average denudation rate in the range did not evolve much between the Middle-Late Pleistocene and Holocene as it varies from $\sim 100 \mathrm{~m} / \mathrm{Myr}$ to $\sim 170 \mathrm{~m} / \mathrm{Myr}$. Accordingly, we propose an average denudation rate in the range of $\sim 135 \mathrm{~m} / \mathrm{Myr}$ for the last $300 \mathrm{kyr}$. In agreement with the other studies performed in the same area, the typical denudation rate of the northern Tian Shan is thus of a few hundred metres per million years at maximum, regardless of the space and time scales. 
This is low for such a high and active mountain belt. From a comparison of the denudation rates observed in the Tian Shan and in other ranges, we suggest that, notwithstanding the tectonic activity, a dry climate can dramatically limit the denudation intensity even in orogenic systems with a strong topographic gradient. As a result, the time required to reach equilibrium between denudation and rock uplift could be extremely long in these systems (more than several million years). Therefore, in such climatic contexts, further work on range uplift and topographic evolution should be carried out to constrain better the state of the system in terms of topographic and flux equilibrium.

\section{Appendix A: Construction of the Morpho-sedimentary Maps}

The two morpho-sedimentary maps are based on the interpretation of Landsat and DigitalGlobe (in Google Earth) satellite images (28 $\mathrm{m}$ and $2.5 \mathrm{~m}$ resolution respectively) coupled with the study of the Aster GDEM2 digital elevation model $(30 \mathrm{~m}$
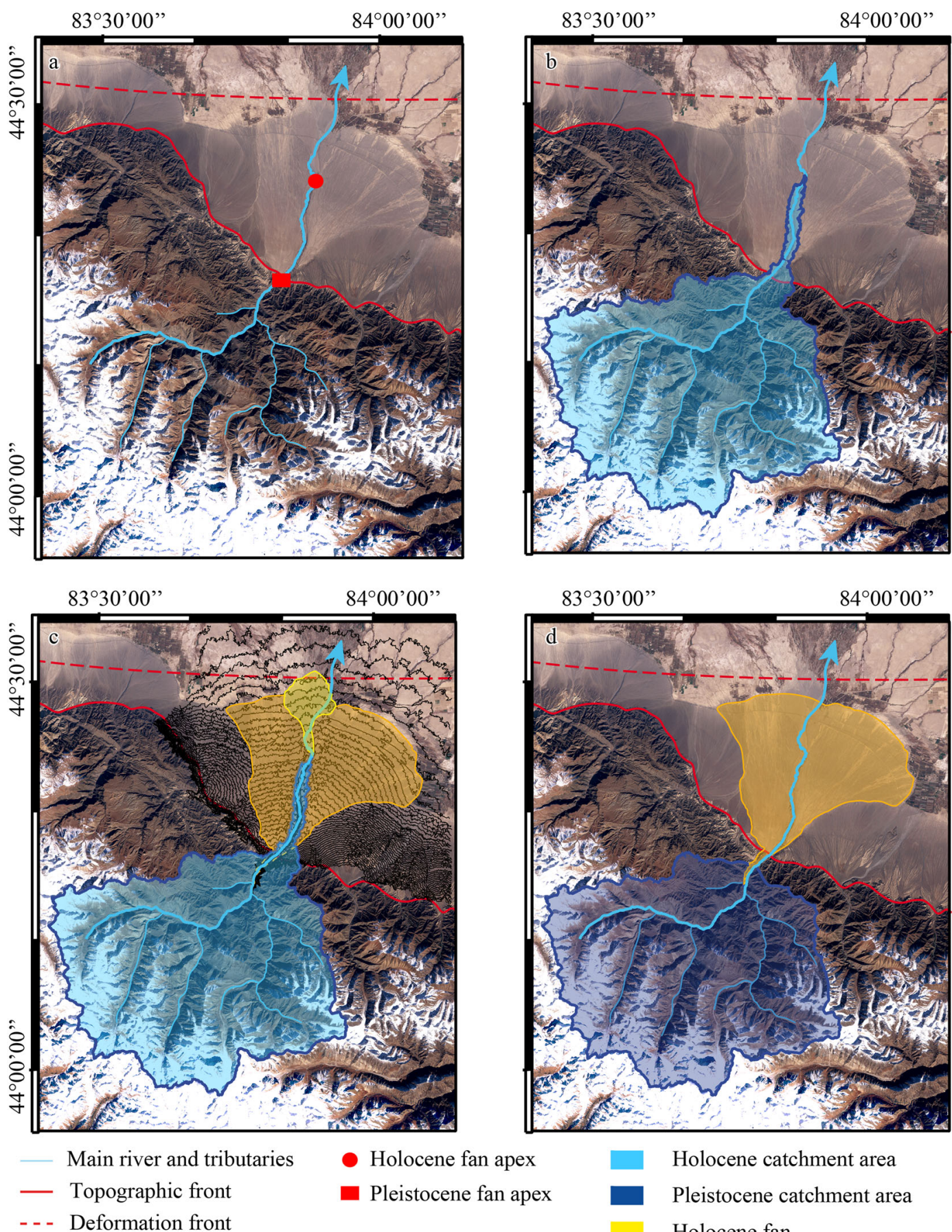

\section{Holocene fan \\ Pleistocene fan}

Figure 12. Construction of the morpho-sedimentary maps based on satellite images and DEM analyses: example of the Guertu River system. (a) Localization of the main river and tributaries (blue lines) and of fan apexes (red square and dot). (b) Determination of the Holocene catchment area. (c) Localization of the Holocene (in yellow) and Middle-Late Pleistocene (in orange) fans. (d) Late Pleistocene map inferred from the Holocene one after the suppression of the Holocene fan and catchment area extension. Below the Holocene fan, the Middle-Late Pleistocene fan outlines are interpolated based on the assumption that the fan termination curve is continuous. The topographic (red line) and deformation (red dash-line) fronts are also indicated. This figure is available in colour online at www.interscience.wiley.com/journal/espl. 
horizontal resolution, 7-14 $\mathrm{m}$ vertical resolution). The same protocol was used to map the 10 catchment-fan systems for which the position of the $F_{p}$ fan basal surface can be identified in the field:

1. The path of the main river and its tributaries were identified from the DEM and the satellite images.

2. The positions of the $F_{p}$ and $F_{h}$ fan apexes along the main stream were identified (Figure 12a).

3. The Holocene drainage basin was extracted from the DEM, considering the $F_{h}$ fan apex as the catchment outlet (Figure 12b).

4. The $F_{p}$ and $F_{h}$ fan outlines were drawn from the satellite images and from the contour lines extracted from the DEM. The fan toes were considered as the slope break between the fan aprons and the surrounding alluvial plain downstream. The alluvial valley upstream of the fan $F_{p}$ was also mapped when it contained an important amount of contemporaneous deposits (see also (Jolivet et al., 2014)). At this point, the morpho-sedimentary map of the present-day landscape in the studied area was obtained (Figure 12c; Data S2 and S3).

5. The morpho-sedimentary map of the Late Pleistocene landscape was inferred from the previous one by the suppression of the fan $\mathrm{F}_{h}$ and the Holocene extension of the drainage basin (i.e. the part of the drainage basin located between the $F_{p}$ and $F_{h}$ apexes). The $F_{p}$ fan outlines were interpolated where missing (e.g. where they were covered by Holocene deposits) and the upstream part of the drainage basin was assumed to be the same during the two periods as there is no evidence for a major catchment evolution in the range from the Middle-Late Pleistocene to the Holocene (Figure 12d; Data S4 and S5).

From the two maps, the drainage basin and fan areas, $A_{d}$ and $A_{F}$ respectively, were extracted (Tables II and III). The uncertainties $\Delta A_{d} / A_{d}$ associated with the drainage basin areas were defined as the overlaps between adjacent catchments and correspond on average to $A_{d} \pm 0.75 \%$ (Tables II and III). Considering that the fan outlines are positioned at the pixel precision, the uncertainties $\Delta A_{F} / A_{F}$ on the fan areas were calculated from the Landsat imagery resolution and are, on average, close to $A_{F} \pm 0.5 \%$ (Tables II and III).

\section{Appendix B: Reconstruction of the Volume of Sediments}

\section{B.1: Middle-Late Pleistocene fan basal surface}

The $F_{p}$ fan basal surfaces were reconstructed from the fan outlines plotted on the morpho-sedimentary maps and from outcrop observations in the field. During two field campaigns, the main Holocene canyons crossing the piedmont were explored and several places where the basal surface of the fans $\mathrm{F}_{p}$ crops out (Figure 3) were identified. The coordinates and elevation of these basal surface outcrops were then defined.

From a position $(x, y, z)$ known thanks to a GPS, three parameters were measured to determine the coordinates of each basal surface outcrop: $A z$, the azimuth of the outcrop line-of-sight obtained with a compass; $\beta$, the angle between the horizontal and the outcrop line-of-sight given by an inclinometer; and $L_{1}$, the distance to the outcrop measured with a distance meter along the line-of-sight. Alternatively, $\beta$ can be replaced by the measurement of $L_{0}$, the horizontal distance to the cliff where the fan base is observed in the $A z$ direction. Coordinates of the basal surface outcrop were then determined by trigonometry (the outcrop $\mathrm{KMZ}$ coordinates are given in Supplementary Data S6).

$\mathrm{Az}, L_{0}$ and $L_{1}$ along three rivers (the Kuitun, Jingou and Urumqi rivers), and $A z, \beta$ and $L_{1}$ along the seven others were measured with 18-95 points for each fan basal surface. The two methods lead to similar accuracy and are sensitive to several parameters: the GPS accuracy $(7-10 \mathrm{~m})$; the compass and inclinometer accuracy (10); and the distance meter maximum capacity $(800 \mathrm{~m})$, which is strongly influenced by the atmospheric conditions, in particular by the presence of dust in the air. Therefore, the coordinates of the basal surfaces were determined within $50 \mathrm{~m}$, which is quite satisfying for the longitude and latitude compared to the length of the fans $F_{p}$ (about $30 \mathrm{~km}$ ). However, this uncertainty is too high for the outcrop elevations. Consequently, the outcrop elevations were not determined directly from field measurements but extracted from the DEM in coherence with estimations made on outcrops and field pictures.

\section{B.2: Fan and sediment volumes}

To obtain the volume of the fans, $V_{F}$, the individual volume of the $250 \times 250 \mathrm{~m}^{2}$ cells of the grids used to model the fan geometry were added up. Consequently, uncertainties on $V_{\mathrm{F}}$ result from the addition of uncertainties on the cell thickness $h$ and the fan area $A_{\mathrm{F}}$. Uncertainties on $h$ correspond to the difference between the two geometric models (produced with linear or cubic interpolations) and are around $1 \%$. Uncertainties on $A_{\mathrm{F}}$ come from the Landsat resolution and are also around $1 \%$. Another source of uncertainties must be added to consider the reconstruction inconsistencies. In fact, in areas where the fan thickness is small, a coherent geometry could not be modelled from the DEM and the field constraints. Each cell with a thickness of less than $5 \mathrm{~m}$ was thus removed from the volume calculation but included in the uncertainties. These cells represent from $1 \%$ to $25 \%$ of the fan areas (Figure $6 \mathrm{e}, \mathrm{f}$ ). Therefore, the uncertainties $\Delta V_{\mathrm{F}} / V_{\mathrm{F}}$ range from $\pm 3 \%$ to $27 \%$ (Tables II and III).

To convert $V_{F}$ into real sediment volumes, $V_{\lambda F}$, the porosity of the deposits was required. As mentioned in the geological setting, all these deposits correspond to conglomerates with grains from silts to metric boulders. From trenches dug in the sediments of the fan $F_{p}$ and of the present-day river bed of the Urumqi River, a porosity $\lambda$ of $20 \pm 10 \%$ was measured for these conglomerates (Guerit, 2014), in good agreement with published values for such a lithology (Clarke, 1979). The uncertainties on the volumes of sediments, $\Delta V_{\lambda F} / V_{\lambda F}$, result from the addition of the uncertainties on $V_{F}$ and $\lambda$. Therefore, they correspond to:

$$
\frac{\Delta V_{\lambda F}}{V_{\lambda F}}=\frac{\Delta V_{F}}{V_{F}}+\frac{\Delta \lambda}{\lambda}
$$

and range from $\pm 13 \%$ to $37 \%$ (Tables II and III).

\section{Appendix C: Estimate of the Denudation Rates}

The uncertainties associated with the Middle-Late Pleistocene and the total Holocene denudation rates, $\epsilon_{p}$ and $\epsilon_{h}$, can be calculated as the sum of the uncertainties on the values used to estimate these rates: the volumes of sediments $V_{\lambda F}$; the proportion of the total sediment load trapped in the fans $\alpha$; the drainage basin areas $A_{d}$; and the duration of the fan construction $P$. Accordingly, the uncertainties associated with 
the Middle-Late Pleistocene denudation rates, $\Delta \epsilon_{p} / \epsilon_{p}$, were calculated as follows:

$$
\frac{\Delta \epsilon_{p}}{\epsilon_{p}}=\frac{\Delta V_{\lambda F_{p}}}{V_{\lambda F_{p}}}+\frac{\Delta \alpha}{\alpha}+\frac{\Delta A_{d p}}{A_{d p}}+\frac{\Delta P_{p}}{P_{p}}
$$

and range between $24 \%$ and $30 \%$ (Table V). Similarly, the uncertainties associated with the total Holocene denudation rates, $\Delta \epsilon_{h} / \epsilon_{h}$, were calculated as follows:

$$
\frac{\Delta \epsilon_{h}}{\epsilon_{h}}=\frac{\Delta V_{\lambda F_{h}}}{V_{\lambda F_{h}}}+\frac{\Delta \alpha}{\alpha}+\frac{\Delta A_{d h}}{A_{d h}}+\frac{\Delta P_{h}}{P_{h}}
$$

and are between $33 \%$ and $58 \%$ (Table V).

The uncertainties associated with the Holocene denudation rates in the piedmont $\epsilon_{c}$ can be calculated as the sum of the uncertainties on the values used to estimate these rates: the volume of sediments reworked from the canyons $V_{\lambda c}$; the areas of the Holocene drainage extensions $A_{d, h-p}$; and the duration of the fan construction $P_{h}$. Accordingly, the uncertainties associated with the Holocene denudation rates in the piedmont, $\Delta \epsilon_{c} / \epsilon_{c}$, were calculated as follows:

$$
\frac{\Delta \epsilon_{c}}{\epsilon_{c}}=\frac{\Delta V_{\lambda c}}{V_{\lambda c}}+\frac{\Delta A_{d, h-p}}{A_{d, h-p}}+\frac{\Delta P_{h}}{P_{h}}
$$

$\Delta A_{d, h-p} / A_{d, h-p}$ being $\Delta A_{d h} / A_{d h}+\Delta A_{d p} / A_{d p}$, and $\Delta V_{\lambda c} / V_{\lambda c}$ being $\Delta V_{c} / V_{c}+\Delta \lambda / \lambda$. Consequently, the Holocene denudation rates in the piedmont are associated with uncertainties of $32-82 \%$ (Table V).

Finally, the uncertainties associated with the Holocene denudation rates in the range $\epsilon_{r}$ can be calculated as the sum of the uncertainties on the values used to estimate these rates: the difference between the volumes of the sediments trapped in the $F_{h}$ fans and those reworked from the canyons $V_{\lambda, F_{h}-c}$; the proportion of the total sediment load trapped in the fans $\alpha$; the areas of the Middle-Late Pleistocene drainage basins $A_{d, p}$; and the duration of the fan construction $P_{h}$. Accordingly, the uncertainties associated with the Holocene denudation rates in the range, $\Delta \epsilon_{r} / \epsilon_{r}$, were calculated as follows:

$$
\frac{\Delta \epsilon_{r}}{\epsilon_{r}}=\frac{\Delta V_{\lambda, F_{h}-c}}{V_{\lambda, F_{h}-c}}+\frac{\Delta \alpha}{\alpha}+\frac{\Delta A_{d p}}{A_{d p}}+\frac{\Delta P_{h}}{P_{h}}
$$

$\Delta V_{\lambda, F_{h}-c} / V_{\lambda, F_{h}-c}$ being $\Delta V_{\lambda F_{h}} / V_{\lambda F_{h}}+\Delta V_{\lambda c} / V_{\lambda c}$. The Holocene denudation rates in the range are thus associated with uncertainties of 33-92\% (Table V).

Acknowledgements - This work was supported by the French CNRS-INSU and the French-Chinese SALADYN International Associated Laboratory. We thank the ESPL Associate Editors and two anonymous reviewers for their very interesting comments that improved the overall quality of the paper. Acknowledgements are also due to N. Shawwa for his editorial assistance. This paper is the IPGP contribution \#3615.

\section{References}

Abdrakhmatov KY, Aldazhanov S, Hager B, Hamburger M, Herring T, Kalabaev K, Makarov V, Molnar P, Panasyuk S, Prilepin M, Reilinger R, Sadybakasov I, Souter B, Trapeznikov Y, Tsurkov V, Zubovich A. 1996. Relatively recent construction of the Tien Shan inferred from GPS measurements of present-day crustal deformation rates. Nature 384: 450-453.

Ahnert F. 1970. Functional relationships between denudation, relief, and uplift in large, mid-latitude drainage basins. American Journal of Science 268(3): 243-263.
Ali SA, Rangzan K, Pirasteh S. 2003. Remote sensing and GIS study of tectonics and net erosion rates in the Zagros structural belt, Southwestern Iran. Mapping Sciences and Remote Sensing 40(4): 258-267.

Allen M, Windley B, Zhang C. 1992. Palaeozoic collisional tectonics and magmatism of the Chinese Tien Shan, central Asia. Tectonophysics 220(1): 89-115.

Allen PA, Hovius N. 1998. Sediment supply from landslide-dominated catchments: implications for basin-margin fans. Basin Research 10(1): 19-35.

Avouac JP, Burov EB. 1996. Erosion as a driving mechanism of intracontinental mountain growth. Journal of Geophysical Research Solid Earth 101(B8): 17747-17769.

Avouac JP, Tapponnier P, Bai M, You H, Wang G. 1993. Active thrusting and folding along the northern Tien Shan and late Cenozoic rotation of the Tarim relative to Dzungaria and Kazakhstan. Journal of Geophysical Research - Solid Earth 98(B4): 6755-6804.

Barnes J, Heins W. 2009. Plio-quaternary sediment budget between thrust belt erosion and foreland deposition in the central Andes, southern Bolivia. Basin Research 21(1): 91-109.

Bhutiyani M. 2000. Sediment load characteristics of a proglacial stream of Siachen Glacier and the erosion rate in Nubra valley in the Karakoram Himalayas, India. Journal of hydrology 227(1): 84-92.

Binnie SA, Phillips WM, Summerfield MA, Fifield LK, Spotila JA. 2010. Tectonic and climatic controls of denudation rates in active orogens: the San Bernardino Mountains, California. Geomorphology 118(3): 249-261.

Brown ET, Stallard RF, Larsen MC, Raisbeck GM, Yiou F. 1995. Denudation rates determined from the accumulation of in situ-produced ${ }^{10} \mathrm{Be}$ in the Luquillo Experimental Forest, Puerto Rico. Earth and Planetary Science Letters 129(1): 193-202.

Bullen M, Burbank D, Garver J. 2003. Building the northern Tien Shan: integrated thermal, structural, and topographic constraints. Journal of Geology 111(2): 149-165.

Burbank D, Blythe A, Putkonen J, Pratt-Sitaula B, Gabet E, Oskin M, Barros A, Ojha T. 2003. Decoupling of erosion and precipitation in the Himalayas. Nature 426(6967): 652-655.

Burchfiel BC, Brown ET, Qidong D, Xianyue F, Jun L, Molnar P, Jianbang S, Zhangming W, Huichuan Y. 1999. Crustal shortening on the margins of the Tien Shan, Xinjiang, China. International Geology Review 41(8): 665-700.

Burtman VS, Skobelev SF, Molnar P. 1996. Late Cenozoic slip on the talas-ferGhana fault, the Tien Shan, central Asia. Geological Society of America Bulletin 108(8): 1004-1021.

Calvès $G$, Toucanne $S$, Jouet $G$, Charrier $S$, Thereau $E$, Etoubleau J, Marsset T, Droz L, Bez M, Jorry S, Mulder T, Lericolais G. 2013. Inferring denudation variations from the sediment record; an example of the last glacial cycle record of the Golo Basin and watershed, East Corsica, western Mediterranean sea. Basin Research 25: 197-218.

Carretier S, Regard V, Vassallo R, Aguilar G, Martinod J, Riquelme R, Pepin E, Charrier R, Hérail G, Farías M, Guyot JL, Vargas G, Lagane C. 2013. Slope and climate variability control of erosion in the Andes of central Chile. Geology 41(2): 195-198.

Carretier S, Regard V, Vassallo R, Martinod J, Christophoul F, Gayer E, Audin L, Lagane C. 2015. A note on ${ }^{10} \mathrm{Be}$-derived mean erosion rates in catchments with heterogeneous lithology: examples from the western Central Andes. Earth Surface Processes and Landforms 40(13): 1719-1729.

Champagnac JD, Molnar P, Sue C, Herman F. 2012. Tectonics, climate, and mountain topography. Journal of Geophysical Research 117: B02403.

Chappell J, Zheng H, Fifield K. 2006. Yangtse River sediments and erosion rates from source to sink traced with cosmogenic ${ }^{10} \mathrm{be}$ : sediments from major rivers. palaeogeography, Palaeoclimatology. Palaeoecology 241(1): 79-94.

Charreau J, Chen Y, Gilder S, Barrier L, Dominguez S, Augier R, Sen S, Avouac JP, Gallaud A, Graveleau F, Wang Q. 2009a. Neogene uplift of the Tian Shan Mountains observed in the magnetic record of the Jingou River section (northwest China). Tectonics 28(2): TC2008.

Charreau J, Gumiaux C, Avouac JP, Augier R, Chen Y, Barrier L, Gilder S, Dominguez S, Charles N, Wang Q. 2009b. The Neogene Xiyu Formation, a diachronous prograding gravel wedge at front of the 
Tianshan: climatic and tectonic implications. Earth and Planetary Science Letters 287: 298-310.

Charreau J, Blard PH, Puchol N, Avouac JP, Lallier-Verges E, Bourles D, Braucher R, Gallaud A, Finkel R, Jolivet M, Chen Y, Roy P. 2011. Paleo-erosion rates in Central Asia since $9 \mathrm{Ma}$ : a transient increase at the onset of Quaternary glaciations? Earth and Planetary Science Letters 304(1-2): 85-92.

Charreau J, Kent-Corson ML, Barrier L, Augier R, Ritts BD, Chen Y, France-Lanord C, Guilmette C. 2012. A high-resolution stable isotopic record from the Junggar Basin (NW China): implications for the paleotopographic evolution of the Tianshan Mountains. Earth and Planetary Science Letters 341: 158-169.

Chen K, Gumiaux C, Augier R, Martelet G, Chen Y, Wang Q. 2014. Integrated multidisciplinary approach to constrain range fronts structure, a case study of the northern Tianshan piedmont (NW China). Bulletin de la Société Géologique de France 185(6): 379-392.

Church M, Ryder JM. 1972. Paraglacial sedimentation: a consideration of fluvial processes conditioned by glaciation. Geological Society of America Bulletin 83(10): 3059-3072.

Church M, Slaymaker O. 1989. Disequilibrium of Holocene sediment yield in glaciated British Columbia. Nature 337(6206): 452-454.

Clarke RH. 1979. Reservoir properties of conglomerates and conglomeratic sandstones. American Association of Petroleum Geologists Bulletin 63(5): 799-809.

Clift PD. 2006. Controls on the erosion of Cenozoic Asia and the flux of clastic sediment to the ocean. Earth and Planetary Science Letters 241(3): 571-580.

Clift PD, Giosan L, Blusztajn J, Campbell I, Allen C, Pringle M, Tabrez A, Danish M, Rabbani M, Alizai A, Carter A, Lueckge A. 2008. Holocene erosion of the Lesser Himalaya triggered by intensified summer monsoon. Geology 36(1): 79-82.

Covault JA, Craddock WH, Romans BW, Fildani A, Gosai M. 2013. Spatial and temporal variations in landscape evolution: historic and longer-term sediment flux through global catchments. Journal of Geology 121: 35-56.

Dadson S, Hovius N, Chen H, Dade W, Hsieh M, Willett S, Hu J, Horng M, Chen M, Stark C, Lague D, Lin J. 2003. Links between erosion, runoff variability and seismicity in the Taiwan orogen. Nature 426(6967): 648-651.

de Vente J, Poesen J, Arabkhedri M, Verstraeten G. 2007. The sediment delivery problem revisited. Progress in Physical Geography 31(2): 155-178.

Delmas M, Braucher R, Gunnell Y, Guillou V, Calvet M, Bourlès D, and ASTER Team. 2015. Constraints on Pleistocene glaciofluvial terrace age and related soil chronosequence features from vertical ${ }^{10}$ Be profiles in the ariège River catchment (pyrenees, France). Global Planet Change 132: 39-53.

Dumitru TA, Zhou D, Chang EZ, Graham SA, Hendrix MS, Sobel ER, Carroll AR. 2001. Uplift, exhumation, and deformation in the Chinese Tian Shan. Memoirs - Geological Society of America 194: 71-100.

Ehlers TA, Farley KA. 2003. Apatite (u-th)/he thermochronometry: methods and applications to problems in tectonic and surface processes. Earth and Planetary Science Letters 206(1): 1-14.

Farías M, Charrier R, Carretier S, Martinod J, Fock A, Campbell D, Cáceres J, Comte D. 2008. Late Miocene high and rapid surface uplift and its erosional response in the Andes of central Chile (330-35o S). Tectonics 27(1): TC1005.

Gabet EJ, Burbank DW, Pratt-Sitaula B, Putkonen J, Bookhagen B. 2008. Modern erosion rates in the High Himalayas of Nepal. Earth and Planetary Science Letters 267(3): 482-494.

Gallaud A. 2008. Interaction Orogenèse - Climat - Erosion en Asie Centrale durant le Cénozoïque : l'impact de la surrection de la chaine du Tianshan sur le climat dans le bassin du Junggar, University Orléans, France.

Galy A, France-Lanord C. 2001. Higher erosion rates in the Himalaya: geochemical constraints on riverine fluxes. Geology 29(1): 23-26.

Gao J, Li M, Xiao X, Tang Y, He G. 1998. Paleozoic tectonic evolution of the Tianshan Orogen, northwestern China. Tectonophysics 287(1-4): 213-231.

Gong Z, Li SH, Li B. 2014. The evolution of a terrace sequence along the Manas River in the northern foreland basin of Tian
Shan, China, as inferred from optical dating. Geomorphology 213 : 201-212.

Granger DE, Kirchner JW, Finkel R. 1996. Spatially averaged long-term erosion rates measured from in situ-produced cosmogenic nuclides in alluvial sediment. Journal of Geology 104: 249-257.

Graveleau F. 2008. Interactions Tectonique, Erosion, Sédimentation dans les avant-pays de chaînes : modélisation analogique et étude des piémonts de l'est du Tian Shan (Asie centrale), Université Montpellier II Sciences et Techniques du Languedoc, France.

Grujic D, Coutand I, Bookhagen B, Bonnet S, Blythe A, Duncan C. 2006. Climatic forcing of erosion, landscape, and tectonics in the Bhutan Himalayas. Geology 34(10): 801-804.

Guan S, Li B, He D, Shaw JH, Chen Z. 2009. Recognition and exploration of structural wedges: a case study in the southern margin of Junggar Basin, China. Earth Science Frontiers 16(3): 129-137.

Guerit L. 2014. Caractéristiques morpho-sédimentaires des cônes alluviaux et reconstitution de leurs paléo-flux d'eau et de sédiments: exemples naturels du piedmont nord du Tian Shan (Xinjiang, Chine) et modélisation expérimentale, Institut de Physique du Globe de Paris, Université Paris Diderot, France.

Heilbronn G, Boulvais P, Marchand E, Robin C, Bourquin S, Barrier L, Jia Y, Fu B. 2015. Stable isotope characterization of pedogenic and lacustrine carbonates from the Chinese Tian Shan: constraints on the Mesozoic-Lower Cenozoic paleo-environmental evolution. Chemie der Erde-Geochemistry 75(1): 133-141.

Henderson R, Thompson S. 1999. Extreme rainfalls in the Southern Alps of New Zealand. Journal of Hydrology (NZ) 38(2): 309-330.

Hendrix M, Graham S, Carroll A, Sobel E, McKnight C, Schulein B, Wang Z. 1992. Sedimentary record and climatic implications of recurrent deformation un the Tian Shan: evidence from mesozoic strata of the north Tarim, south Junggar, and Turpan basins, northwest China. Geological society of America Bulletin 104(1): 53-79.

Hendrix MS, Dumitru TA, Graham SA. 1994. Late Oligocene-early Miocene unroofing in the Chinese Tian Shan: an early effect of the India-asia collision. Geology 22(6): 487-490.

Herman F, Rhodes E, Braun J, Heiniger L. 2010. Uniform erosion rates and relief amplitude during glacial cycles in the Southern Alps of New zealand, as revealed from OSL-thermochronology. Earth and Planetary Science Letters 297: 183-189.

Hinderer M. 2012. From gullies to mountain belts: a review of sediment budgets at various scales. Sedimentary Geology 280: 21-59.

Hippe K, Kober F, Zeilinger G, Ivy-Ochs S, Maden C, Wacker L, Kubik PW, Wieler R. 2012. Quantifying denudation rates and sediment storage on the eastern Altiplano, Bolivia, using cosmogenic ${ }^{10} \mathrm{Be}$, ${ }^{26} \mathrm{Al}$, and in situ ${ }^{14} \mathrm{C}$. Geomorphology 179: 58-70.

Hoffmann T, Erkens G, Cohen KM, Houben P, Seidel J, Dikau R. 2007. Holocene floodplain sediment storage and hillslope erosion within the Rhine catchment. The Holocene 17(1): 105-118.

Hornung J, Pflanz D, Hechler A, Beer A, Hinderer M, Maisch M, Bieg U. 2010. 3-D architecture, depositional patterns and climate triggered sediment fluxes of an alpine alluvial fan (Samedan, Switzerland). Geomorphology 115: 202-214.

Hovius N. 1998. Controls on sediment supply by large rivers. Special Publications of SEPM 59: 3-16.

laffaldano G, Husson L, Bunge HP. 2011. Monsoon speeds up Indian plate motion. Earth and Planetary Science Letters 304(3): 503-510.

Insel N, Ehlers TA, Schaller M, Barnes JB, Tawackoli S, Poulsen CJ. 2010. Spatial and temporal variability in denudation across the Bolivian Andes from multiple geochronometers. Geomorphology 122(1): 65-77.

Javanmard S, Yatagai A, Nodzu M, BodaghJamali J, Kawamoto H. 2010. Comparing high-resolution gridded precipitation data with satellite rainfall estimates of TRMM 3B42 over Iran. Advances in Geosciences 25: 119-125.

Jayko AS. 2005. Late Quaternary denudation, Death and Panamint valleys, eastern California. Earth-Science Reviews 73(1): 271-289.

Jolivet M, Ritz JF, Vassallo R, Larroque C, Braucher R, Todbileg M, Chauvet A, Sue C, Arnaud N, De Vicente R, Arzhanikova A, Arzhanikov S. 2007. The Mongolian summits: an uplifted, flat, old but still preserved erosion surface. Geology 35(10): 871-874. 
Jolivet M, Dominguez S, Charreau J, Chen Y, Li Y, Wang Q. 2010. Mesozoic and Cenozoic tectonic history of the central Chinese Tian Shan: reactivated tectonic structures and active deformation. Tectonics 29: TC6019.

Jolivet M, Arzhannikov S, Arzhannikova A, Chauvet A, Vassallo R, Braucher R. 2013a. Geomorphic Mesozoic and Cenozoic evolution in the Oka-Jombolok region (east sayan ranges, siberia). Journal of Asian Earth Sciences 62: 117-133.

Jolivet M, Heilbronn G, Robin C, Barrier L, Bourquin S, Guo Z, Jia Y, Guerit L, Yang W, Fu B. 2013b. Reconstructing the Late Palaeozoic-Mesozoic topographic evolution of the Chinese Tian Shan: available data and remaining uncertainties. Advances en Geosciences 1: 1-12.

Jolivet M, Barrier L, Dominguez S, Guerit L, Heilbronn G, Fu B. 2014. Unbalanced sediment budgets in the catchment-alluvial fan system of the Kuitun River (northern Tian Shan, China): implications for the erosion and uplift rate estimates in mountain ranges. Geomorphology 214: 168-182.

Kiefer E, Dorr MJ, Ibbeken H, Gotze HJ. 1997. Gravity-based mass balance of an alluvial fan giant: the Arcas Fan, Pampa del Tamarugal, Northern Chile. Andean Geology 24(2): 165-185.

Kirchner J, Finkel R, Riebe C, Granger D, Clayton J, King J, Megahan W. 2001. Mountain erosion over 10 yr, 10 k.y., and 10 m.y. time scales. Geology 29(7): 591-594.

Kober F, Ivy-Ochs S, Schlunegger F, Baur H, Kubik PW, Wieler R. 2007. Denudation rates and a topography-driven rainfall threshold in northern Chile: multiple cosmogenic nuclide data and sediment yield budgets. Geomorphology 83: 97-120.

Kong P, Na C, Fink D, Ding L, Huang F. 2007. Erosion in northwest Tibet from in-situ-produced cosmogenic ${ }^{10} \mathrm{Be}$ and ${ }^{26} \mathrm{Al}$ in bedrock. Earth Surface Processes and Landforms 32(1): 116-125.

Lal D, Harris NB, Sharma KK, Gu Z, Ding L, Liu T, Dong W, Caffee MW, Jull A. 2004. Erosion history of the Tibetan Plateau since the last interglacial: constraints from the first studies of cosmogenic ${ }^{10} \mathrm{Be}$ from Tibetan bedrock. Earth and Planetary Science Letters 217(1): 33-42.

Lane EW, Borland WM. 1951. Estimating bed load. Transactions American Geophysical Union 32: 121-123.

Li Y, Liu G, Cui Z. 2001. Glacial valley cross-profile morphology, Tian Shan Mountains, China. Geomorphology 38(1): 153-166.

Liu Y, Métivier F, Gaillardet J, Ye B, Meunier P, Narteau C, Lajeunesse E, Han T, Malverti L. 2011. Erosion rates deduced from seasonal mass balance along the upper Urumqi River in Tianshan. Solid Earth 2: 283-301.

Lu H, Burbank DW, Li Y. 2010. Alluvial sequence in the north piedmont of the Chinese Tian Shan over the past $550 \mathrm{kyr}$ and its relationship to climate change. Palaeogeogr Palaeoclimatol Palaeoecol 285(3-4): 343-353.

Matmon A, Bierman P, Larsen J, Southworth S, Pavich M, Caffee M. 2003. Temporally and spatially uniform rates of erosion in the southern Appalachian Great Smoky Mountains. Geology 31(2): 155-158.

Matmon A, Simhai O, Amit R, Haviv I, Porat N, McDonald E, Benedetti L, Finkel R. 2009. Desert pavement-coated surfaces in extreme deserts present the longest-lived landforms on Earth. Geological Society of America Bulletin 121(5-6): 688-697.

Métivier F, Gaudemer Y. 1997. Mass transfer between eastern Tien Shan and adjacent basins (central asia): Constraints on regional tectonics and topography. Geophysical Journal International 128(1): $1-17$.

Metivier F, Gaudemer Y. 1999. Stability of output fluxes of large rivers in South and East Asia during the last 2 million years: implications on floodplain processes. Basin Research 11(4): 293-303.

Métivier F, Gaudemer Y, Tapponnier P, Klein M. 1999. Mass accumulation rates in Asia during the Cenozoic. Geophysical Journal International 137(2): 280-318.

Meunier P, Métivier F, Lajeunesse E, Mériaux A, Faure J. 2006. Flow pattern and sediment transport in a braided river: the 'torrent de St Pierre' (french alps). Journal of Hydrology 330(3): 496-505.

Molnar P, England P. 1990. Late Cenozoic uplift of mountain ranges and global climate change: chicken or egg? Nature 346: 29-34.

Molnar PP, Brown ET, Burchfiel BC, Qidong D, Xianyue F, Jun L, Raisbeck GM, Jianbang S, Zhangming W, Yiou F, Huichuan Y.
1994. Quaternary climate change and the formation of river terraces across growing anticlines on the north flank of the Tien Shan, China. Journal of Geology 102(5): 583-602.

Montgomery DR, Brandon MT. 2002. Topographic controls on erosion rates in tectonically active mountain ranges. Earth and Planetary Science Letters 201(3-4): 481-489.

Norris RJ, Toy VG. 2014. Continental transforms: a view from the Alpine Fault. Journal of Structural Geology 64: 3-31.

Norton KP, von Blanckenburg F, DiBiase R, Schlunegger F, Kubik PW. 2011. Cosmogenic ${ }^{10}$ Be-derived denudation rates of the Eastern and Southern European Alps. International Journal of Earth Sciences 100(5): 1163-1179.

Oguchi T. 1997. Late quaternary sediment budget in alluvialfan-source-basin systems in Japan. Journal of Quaternary 12(5): 381-390.

Palumbo L, Hetzel R, Tao M, Li X. 2010. Topographic and lithologic control on catchment-wide denudation rates derived from cosmogenic $10 \mathrm{Be}$ in two mountain ranges at the margin of NE Tibet. Geomorphology 117(1): 130-142.

Palumbo L, Hetzel R, Tao M, Li X. 2011. Catchment-wide denudation rates at the margin of NE Tibet from in situ-produced cosmogenic ${ }^{10}$ Be. Terra Nova 23(1): 42-48.

Pan B, Geng H, Hu X, Sun R, Wang C. 2010. The topographic controls on the decadal-scale erosion rates in Qilian Shan Mountains, NW China. Earth and Planetary Science Letters 292(1-2): 148-157.

Poisson B. 2002. Impact du climat et de la tectonique sur l'évolution géomorphologique d'un piedmont: exemple du piémont Nord du Tian Shan depuis la fin du Pléistocène, Université Paris XI, France.

Poisson B, Avouac J. 2004. Holocene hydrological changes inferred from alluvial stream entrenchment in North Tian Shan (northwestern China). Journal of Geology 112(2): 231-249.

Puchol N. 2013. Détermination des paléo-taux d'érosion par l'utilisation des isotopes cosmogéniques. Cas de la transition Pliocène-Pléistocène, Université de Lorraine, France.

Raymo M, Ruddiman WF. 1992. Tectonic forcing of late Cenozoic climate. Nature 359(6391): 117-122.

Reigber C, Michel G, Galas R, Angermann D, Klotz J, Chen J, Papschev A, Arslanov R, Tzurkov V, Ishanov M. 2001. New space geodetic constraints on the distribution of deformation in Central Asia. Earth and Planetary Science Letters 191(1): 157-165.

Reiners PW, Ehlers TA, Mitchell SG, Montgomery DR. 2003. Coupled spatial variations in precipitation and long-term erosion rates across the Washington Cascades. Nature 426(6967): 645-647.

Retallack GJ. 1997. Colour Guide to Paleosols. Wiley: Chichester.

Rhodes T, Gasse F, Lin R, Fontes J, Wei K, Bertrand P,

Gibert E, Melieres F, Tucholka P, Wang Z, Cheng Z. 1996. A late Pleistocene-Holocene lacustrine record from Lake Manas, Zunggar (northern Xinjiang, western China). palaeogeography, Palaeoclimatology. Palaeoecology 120(1-2): 105-121.

Riebe C, Kirchner J, Granger D, Finkel R. 2001. Strong tectonic and weak climatic control of long-term chemical weathering rates. Geology 29(6): 511-514.

Safran EB, Bierman PR, Aalto R, Dunne T, Whipple KX, Caffee M. 2005. Erosion rates driven by channel network incision in the Bolivian Andes. Earth Surface Processes and Landforms 30(8): 1007-1024.

Schaller M, von Blanckenburg F, Hovius N, Kubik P. 2001. Large-scale erosion rates from in situ-produced cosmogenic nuclides in European river sediments. Earth and Planetary Science Letters 188(3-4): $441-458$.

Schiefer E, Hassan MA, Menounos B, Pelpola CP, Slaymaker O. 2010. Interdecadal patterns of total sediment yield from a montane catchment, southern Coast Mountains, British Columbia, Canada. Geomorphology 118(1-2): 207-212.

Simoes M, Braun J, Bonnet S. 2010. Continental-scale erosion and transport laws: a new approach to quantitatively investigate macroscale landscapes and associated sediment fluxes over the geological past. geochemistry, Geophysics. Geosystems 11(9): Q09001.

Sobel ER, Hilley GE, Strecker MR. 2003. Formation of internally drained contractional basins by aridity-limited bedrock incision. Journal of Geophysical Research: Solid Earth (1978-2012) 108(B7): 2344. 
Summerfield M, Hulton N. 1994. Natural controls of fluvial denudation rates in major world drainage basins. Journal of Geophysical Research: Solid Earth (1978-2012) 99(B7): 13871-13883.

Sun J, Zhang Z. 2008. Palynological evidence for the mid-Miocene climatic optimum recorded in Cenozoic sediments of the Tian Shan Range, northwestern China. Global Planet Change 64(1): 53-68.

Tapponnier P, Molnar P. 1977. Active faulting and tectonics in China. Journal of Geophysical Research 82(20): 2905-2930.

Torres Acosta V, Schildgen TF, Clarke BA, Scherler D, Bookhagen B, Wittmann H, von Blanckenburg F, Strecker MR. 2015. Effect of vegetation cover on millennial-scale landscape denudation rates in East Africa. Lithosphere L402: 1.

Vance D, Bickle M, Ivy-Ochs S, Kubik P. 2003. Erosion and exhumation in the Himalaya from cosmogenic isotope inventories of river sediments. Earth and Planetary Science Letters 206(3-4): 273-288.

von Blanckenburg F. 2005. The control mechanisms of erosion and weathering at basin scale from cosmogenic nuclides in river sediment. Earth and Planetary Science Letters 237(3): 462-479.

Whipple KX. 2009. The influence of climate on the tectonic evolution of mountain belts. Nature Geoscience 2(2): 97-104.

Windley BF, Allen MB, Zhang C, Zhao ZY, Wang GR. 1990. Paleozoic accretion and Cenozoic redeformation of the Chinese Tien Shan range, central Asia. Geology 18(2): 128-131.

Winiger M, Gumpert M, Yamout H. 2005. Karakorum-hindukushwestern Himalaya: assessing high-altitude water resources. Hydrological Processes 19(12): 2329-2338.

Wittmann H, von Blanckenburg F, Kruesmann T, Norton KP, Kubik PW. 2007. Relation between rock uplift and denudation from cosmogenic nuclides in river sediment in the Central Alps of Switzerland. Journal of Geophysical Research: Earth Surface 112: F04010.

Xu X, Kleidon A, Miller L, Wang S, Wang L, Dong G. 2010. Late Quaternary glaciation in the Tianshan and implications for palaeoclimatic change: a review. Boreas 39(2): 215-232.
Yang X, Li A, Hunag W. 2013. Uplift differential of active fold zones during the late Quaternary, northern piedmonts of the Tianshan Mountains, China. Science China Earth Sciences 56(5): 794-805.

Yi C, Liu K, Cui Z, Jiao K, Yao T, He Y. 2004. AMS Radiocarbon dating of late Quaternary glacial landforms, source of the Urumqi River, Tien Shan: a pilot study of ${ }^{14} \mathrm{C}$ dating on inorganic carbon. Quaternary International 121(1): 99-107.

Zhang P, Molnar P, Downs W. 2001. Increased sedimentation rates and grain sizes 2-4 Myr ago due to the influence of climate change on erosion rates. Nature 410(6831): 891-897.

Zhao J, Liu S, He Y, Song Y. 2009. Quaternary glacial chronology of the Ateaoyinake River Valley, Tianshan Mountains, China. Geomorphology 103: 276-284.

Zhou D, Graham SA, Chang EZ, Wang B, Hacker B. 2001. Paleozoic tectonic amalgamation of the Chinese Tian Shan: evidence from a transect along the Dushanzi-Kuqa Highway. Memoirs - Geological Society of America 194: 23-46.

Zhou L, Yang F, Shao X. 1999. River Hydrology and Water Resources in Xinjiang, Urumqi (in Chinese). Xinjiang Science and Technology Press: Xinjiang, China.

Zhou SZ, Jiao KQ, Zhao JD, Zhang SQ, Cui JX, Xu LB. 2002. Geomorphology of the Urumqi River Valley and the uplift of the Tianshan Mountains in Quaternary. Science China Series D : Earth Sciences 45(11): 961-968.

Zubovich AV, Wang Xq, Scherba YG, Schelochkov GG, Reilinger R, Reigber C, Mosienko OI, Molnar P, Michajljow W, Makarov VI, Li J, Kuzikov S, Herring T, Hamburger M, Bradford H, Dang Y, Bragin V, Beisenbaev R. 2010. GPS velocity field for the Tien Shan and surrounding regions. Tectonics 29(6): TC6014.

\section{Supporting Information}

Supporting information may be found in the online version of this article at the publisher's web site. 